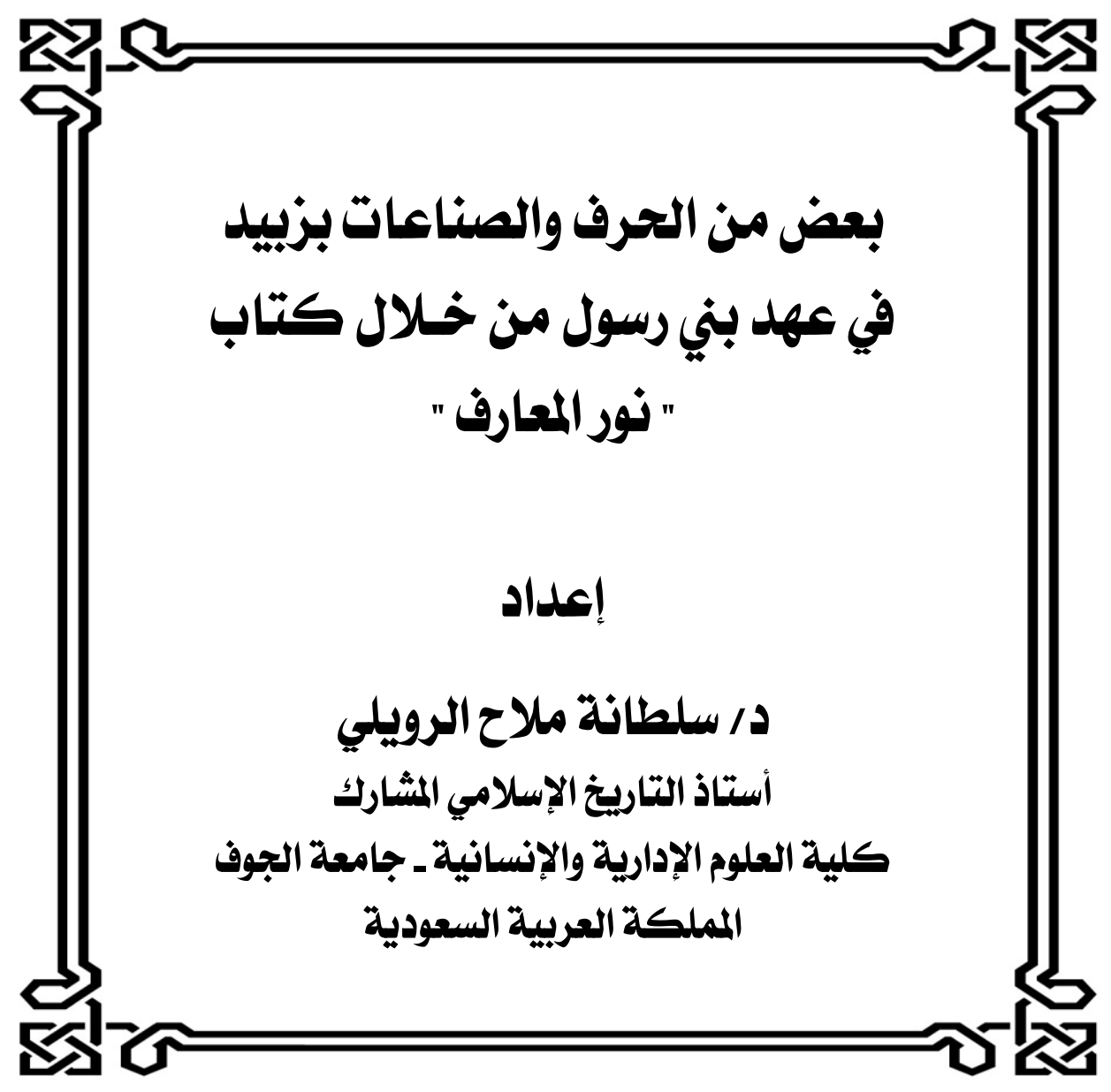


د/ سلطانه ملاح الرويلي بصض من الحرف والصناعات بزبيد في عهد بني رسول من خلا كتاب " نور المعارف"

$=$ TYY

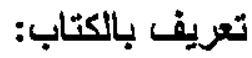

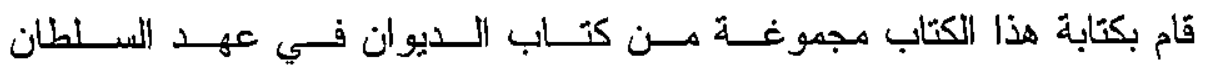

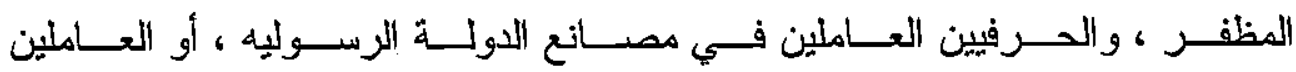

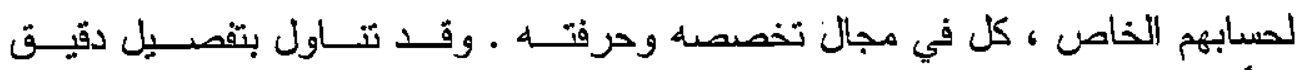

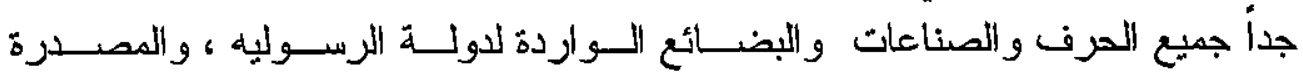

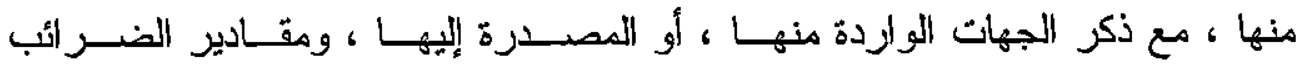

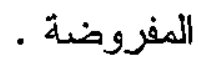

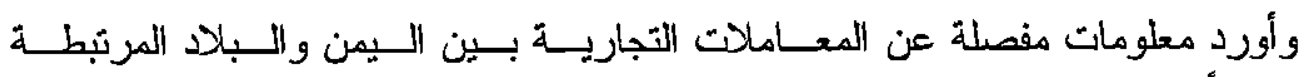

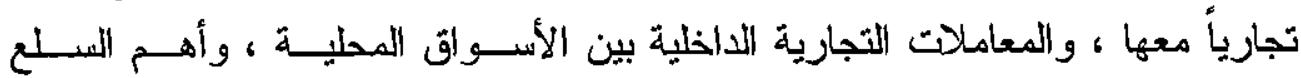

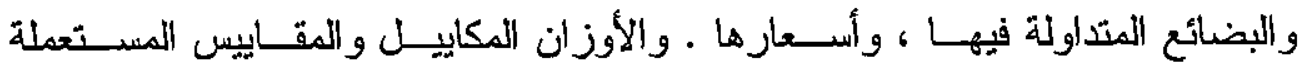

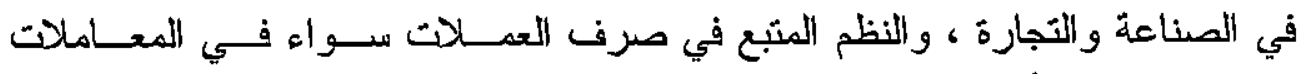
• التجاربة الاخلية أو. الخارجية .

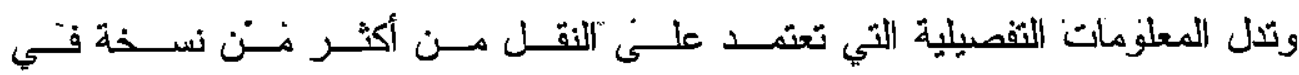

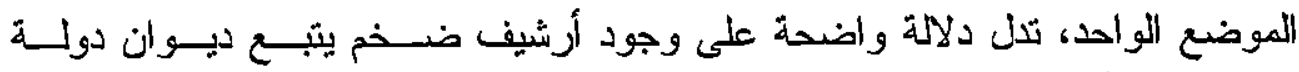

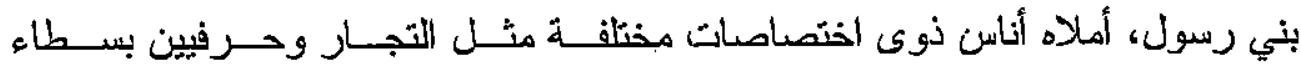

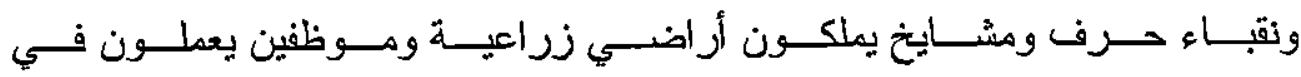

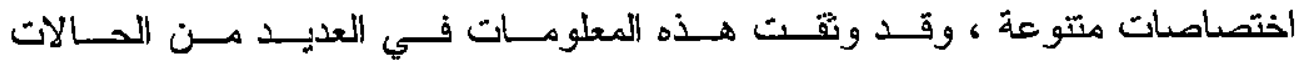

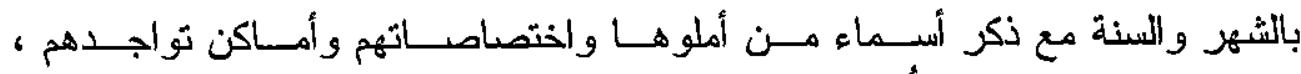

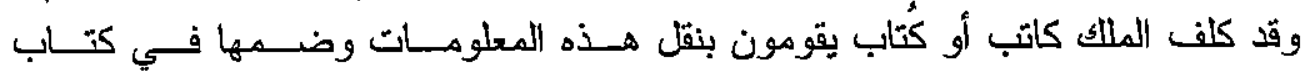

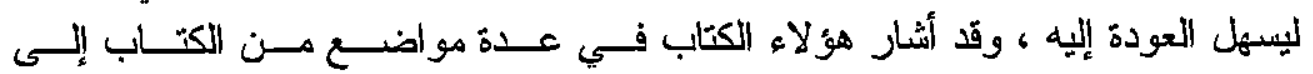

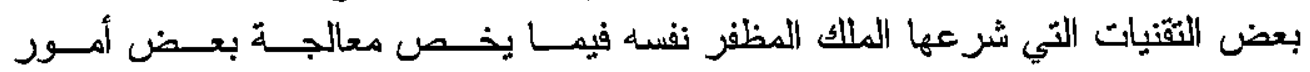

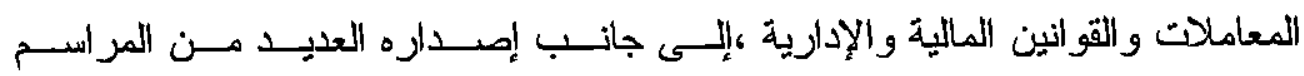
السلطانية المتعلقة بالإدارة وغيرها (1) 
د/ سلطانه ملاح الرويلي بعض من الحرف والصناعات بزبيد في عهل بني رسول

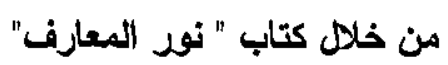

$=\frac{\mathrm{err}}{\mathrm{rr}}$

وكان هذا الكتاب بمثابة المصدر الأساسي في هذا البحث حيث استفادة الباحثة منه في الحديث غن الأساليب في وصف المصنوعات اليمينية وأساليب صناعتها وتكاليفها وضرائبها، وفي الحديث عن أهم واردات اليمن وصن وصادر اتها.

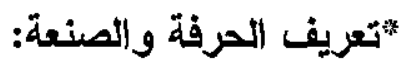

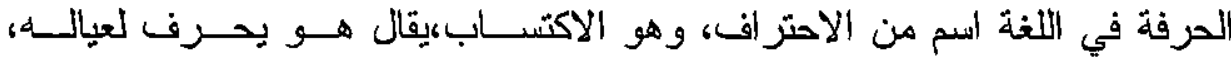

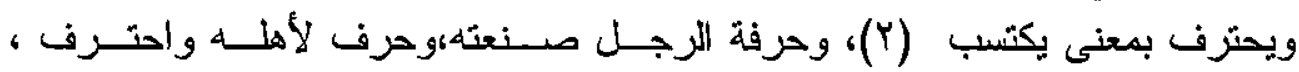

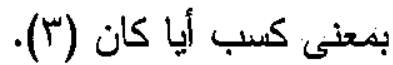

أما الحرفة في المعنى الاصطلاحي فهي: الصناعة التي يرتزق منها، وهى جهة

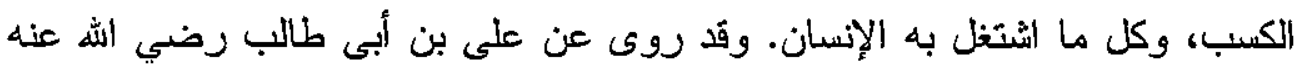

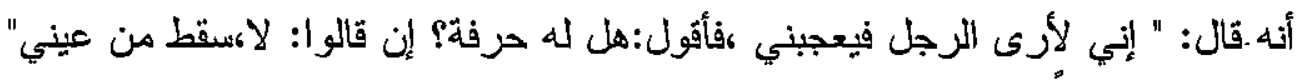
(ع فالحرفة إذاً نطلق على كل عمل يقوم به الإنسان، فهي طريقة الكسب، ووسيلة

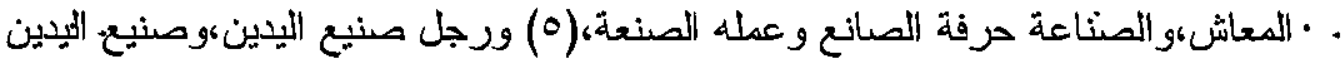

أي صنانع حاذق بعمل اليدين (T).

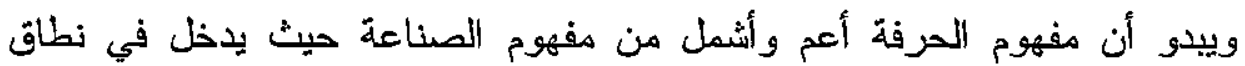

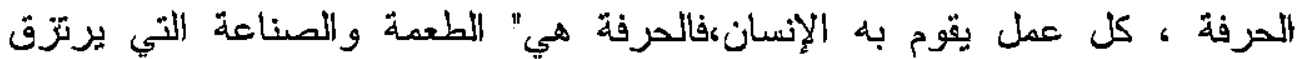

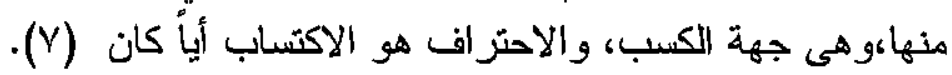

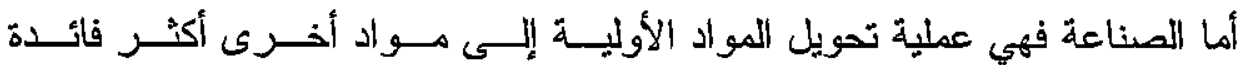

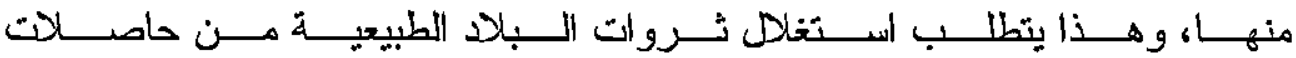

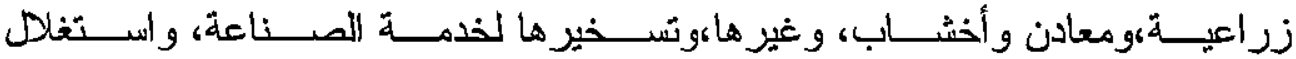

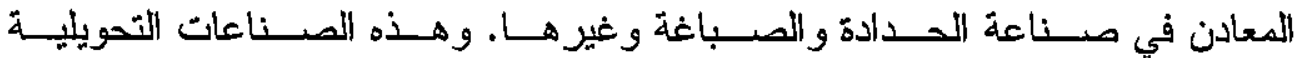

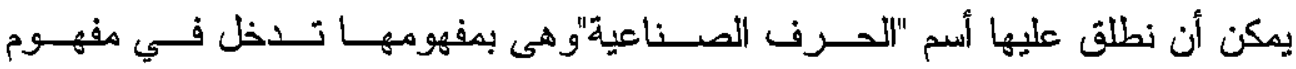

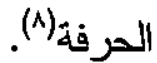

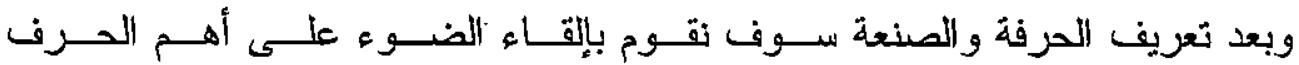
و الصناعات الثي قام بها اليمنيون. 
د/ سلطانه ملاح الرويلي بعض من الحرف والصناعات بزبيد في عها بني رسول

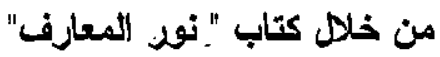

$=$ rYE

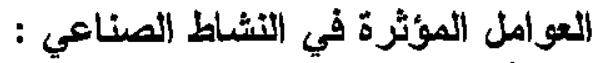

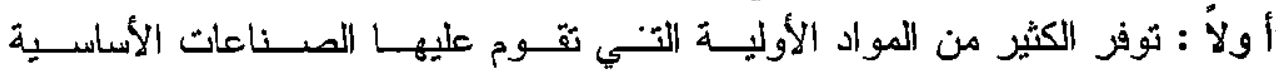

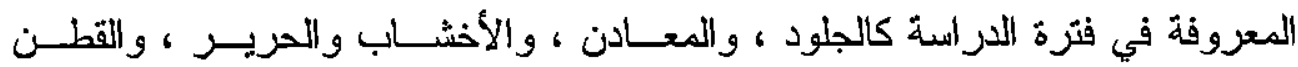

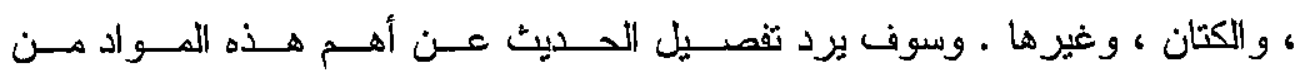

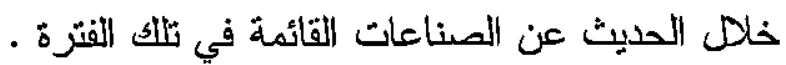
ثانياً:وفزة الأيدي العاملة : العناعات

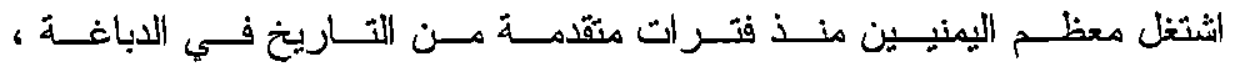

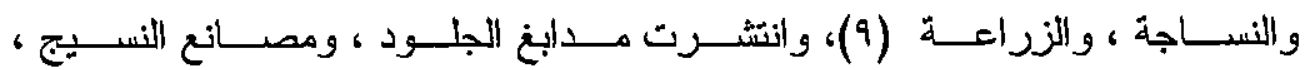

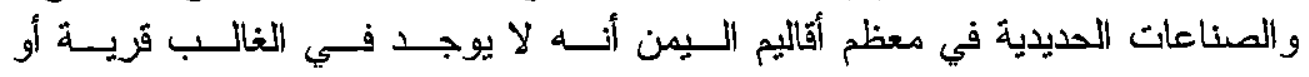

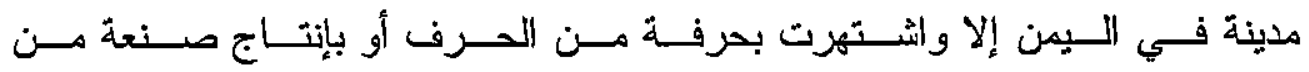
الصناعات القديمة (·) (1).

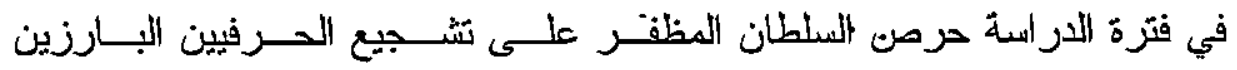

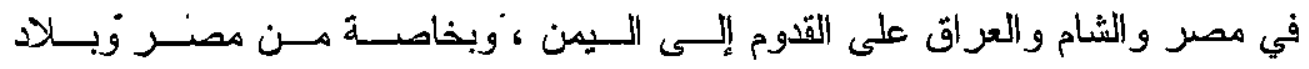

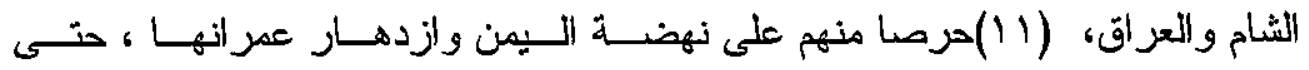

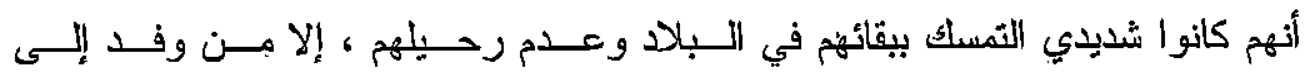

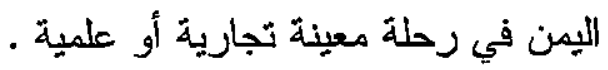

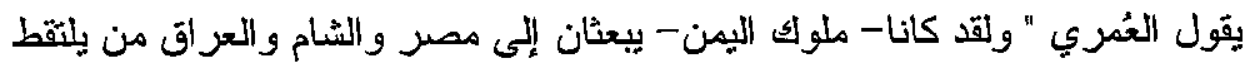

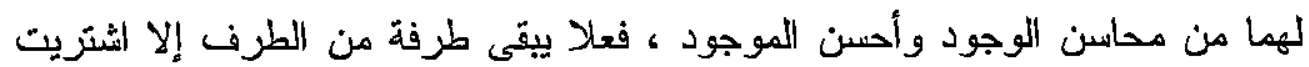

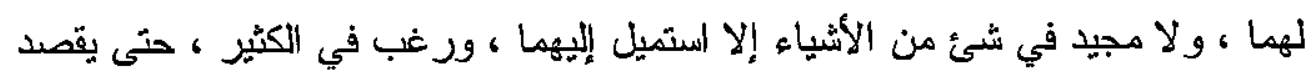

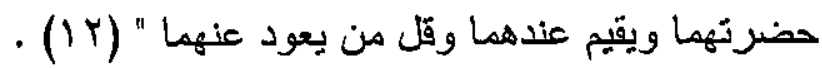

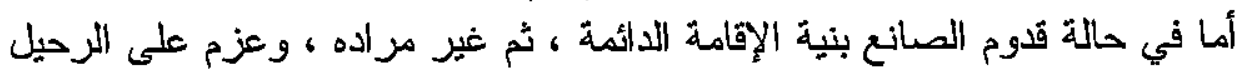

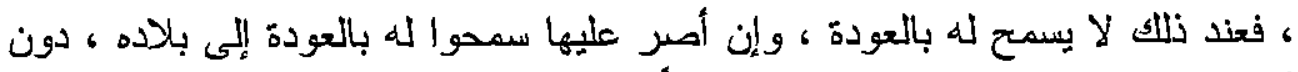

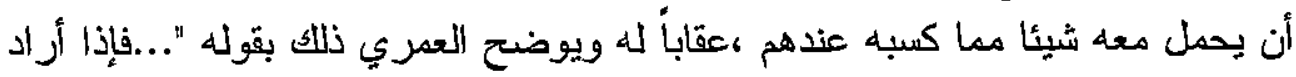

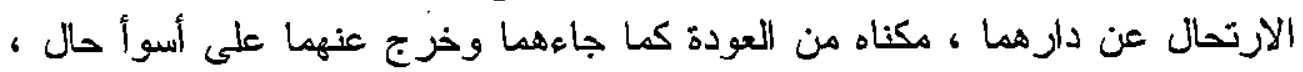


/ / سلطانه ملاح الزويلي بعض من الحرف والصناعات بزبيد في عهل بني رسول

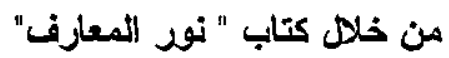

\section{$=$ rro}

مسلوباً بما استفاد عندهما من نعمة ومال ؛ عقاباً له على مفارقته لأبو ابهها ، لا بُخلا

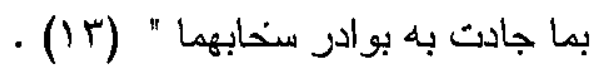

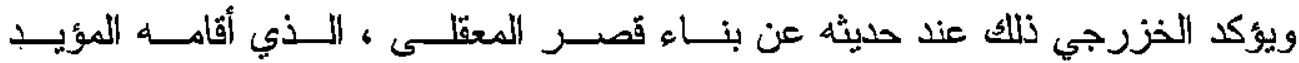

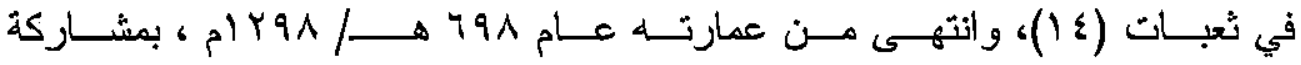

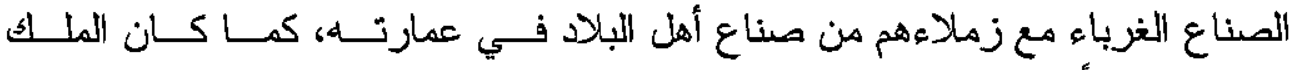

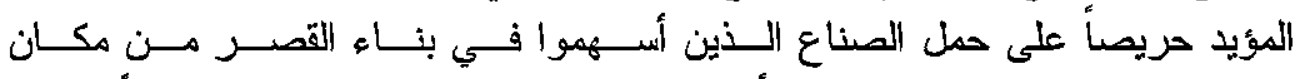

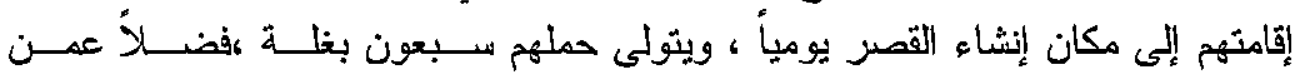

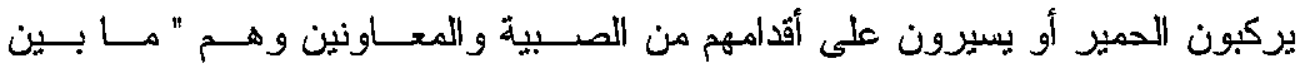

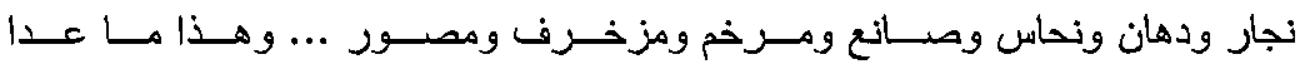

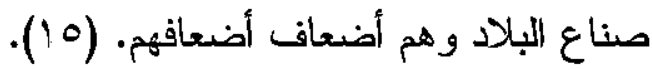

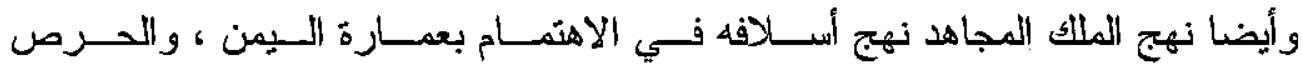

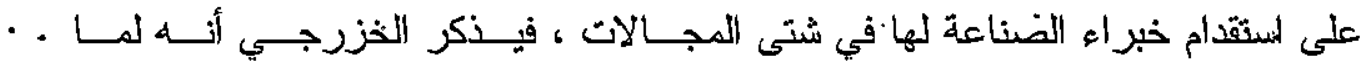

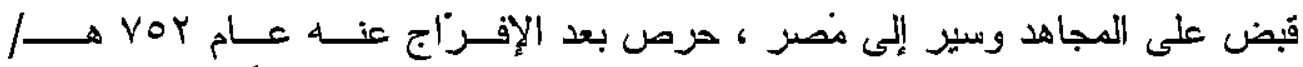

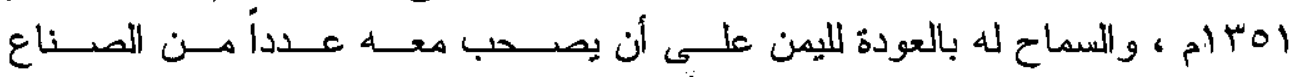

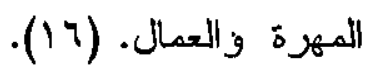

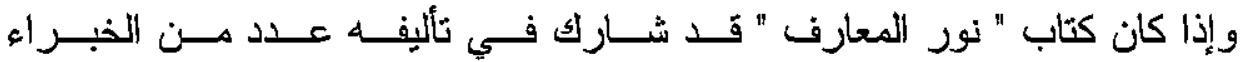

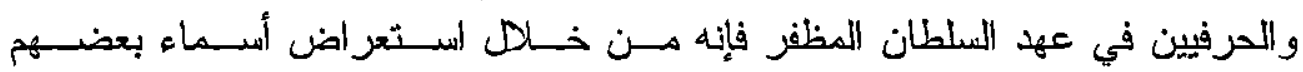

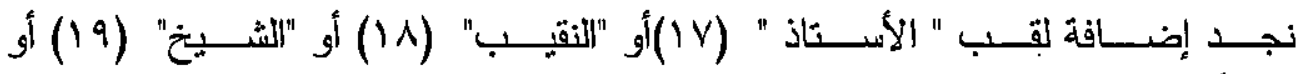

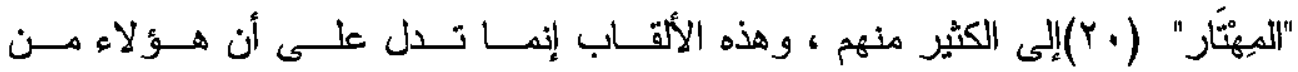

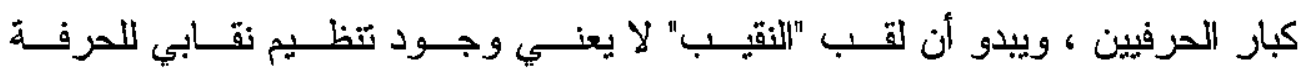

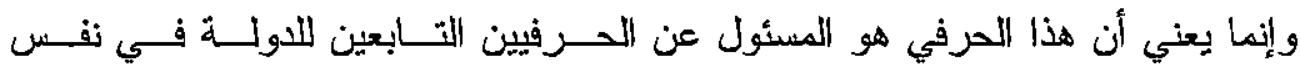

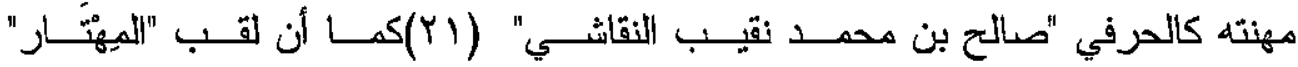

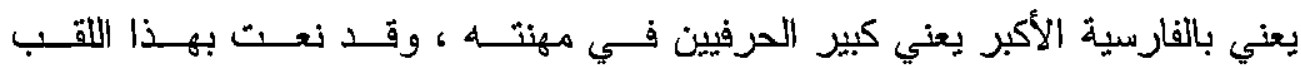

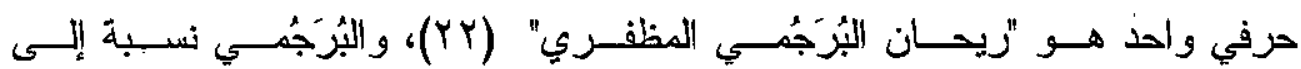


د/ سلطانه ملاح الرويلي بصض من الحرف والصناعات بزبيا في عهل بني رسول هن خلال كتاب " نور المعارف"

$=\%$ TrT

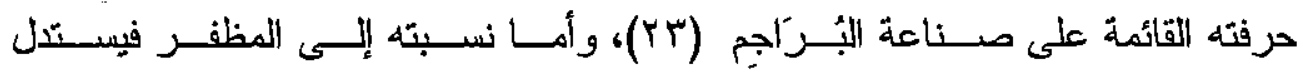

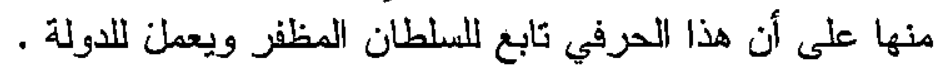

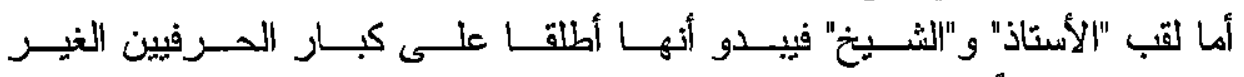

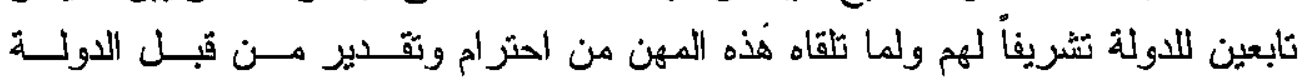

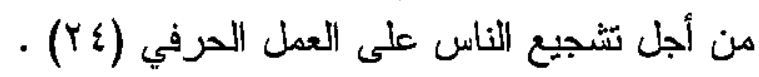

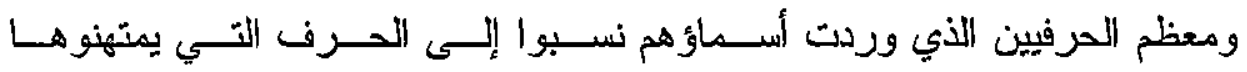

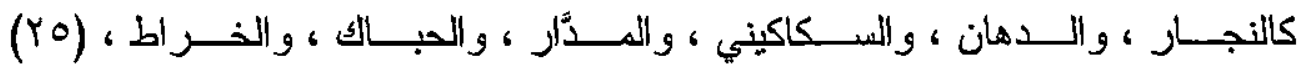

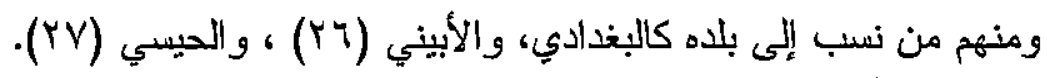

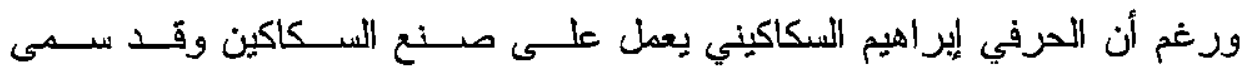

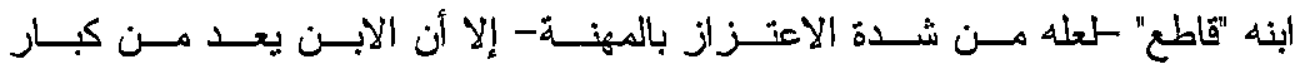

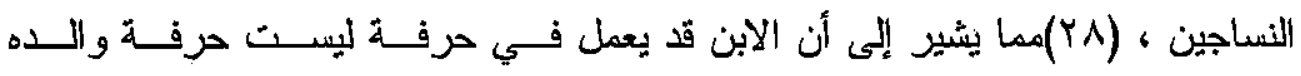
ويبدع فيها .

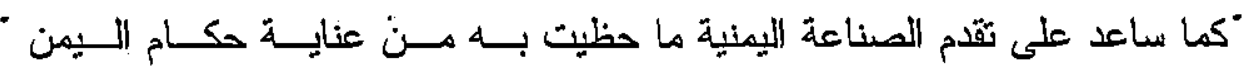

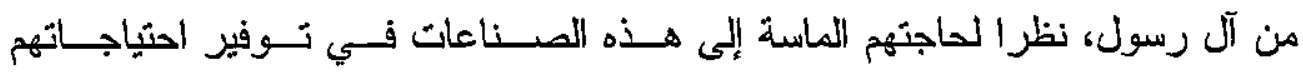

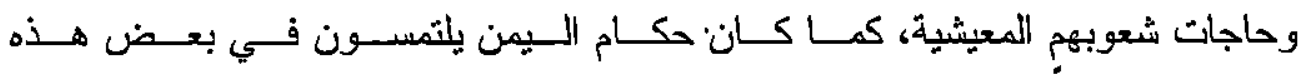

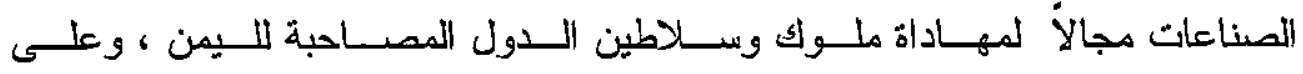

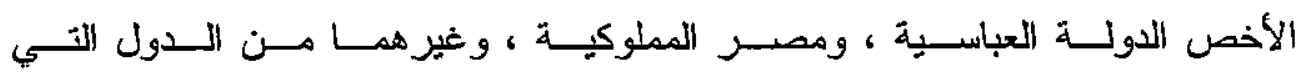

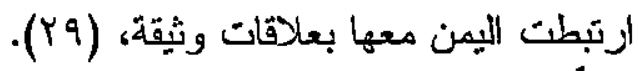

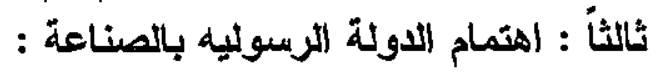

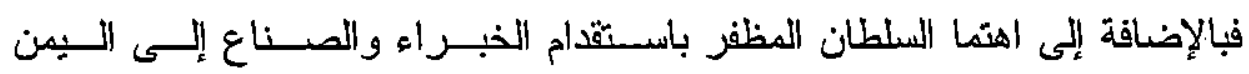

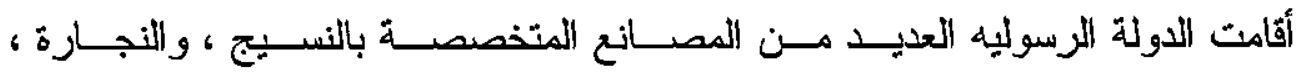

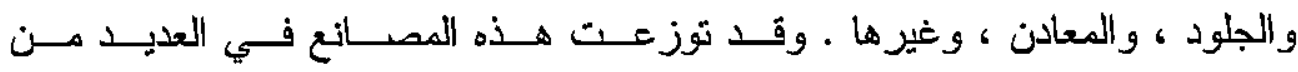

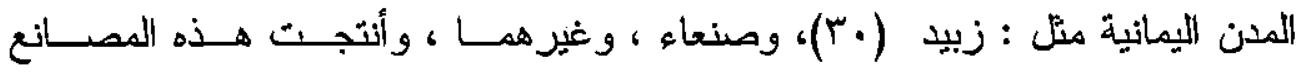

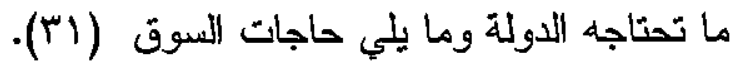


د/ سلطانه ملاح الرويلي بعض من الحرف والصناعات بزبيد في عهد بني رسول

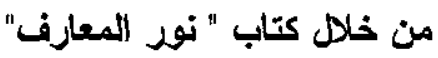

$=$ TrV

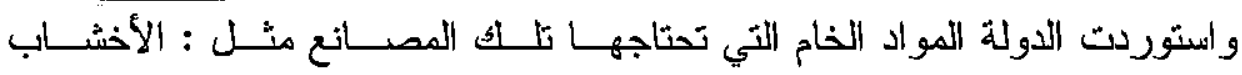

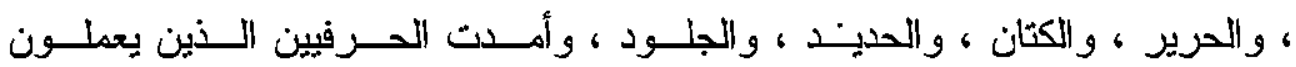

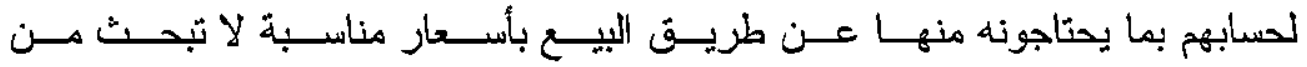

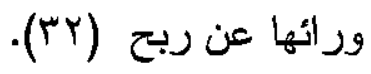

r - النشاط الصناعي والحرفي بزبيد:

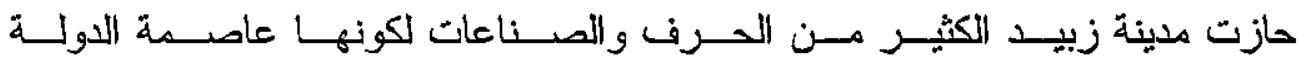

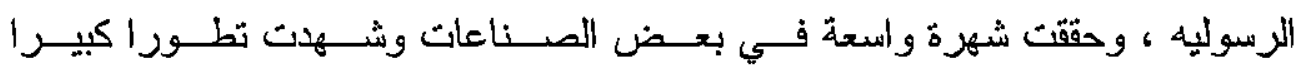

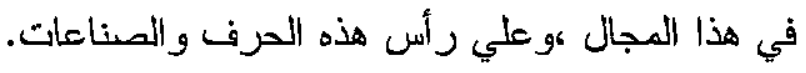
1-صناعة الفخار :

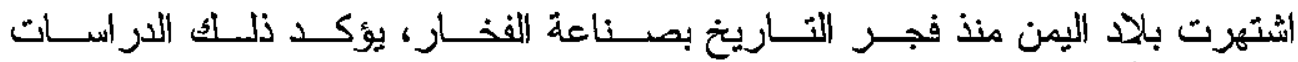

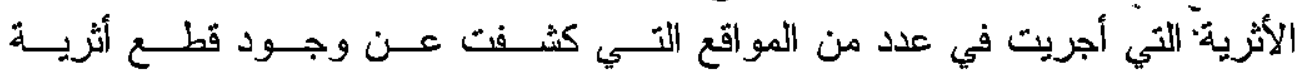

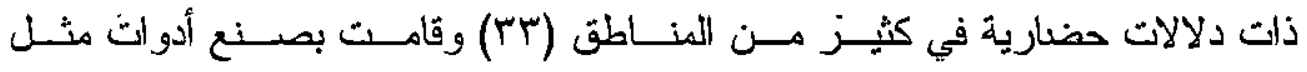

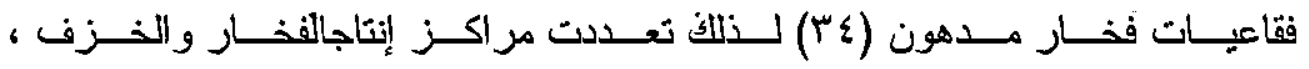

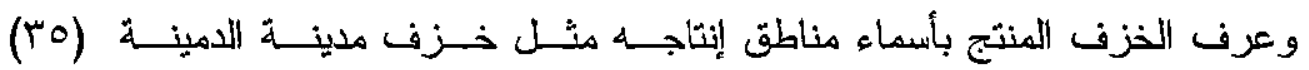

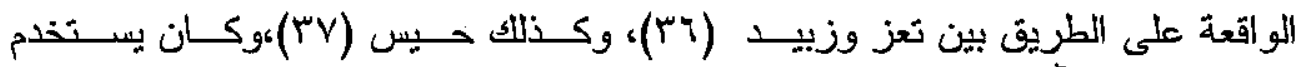

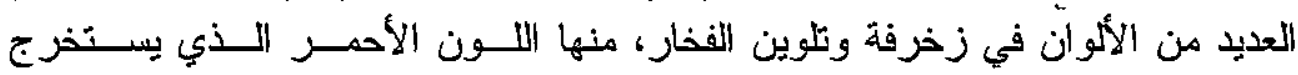

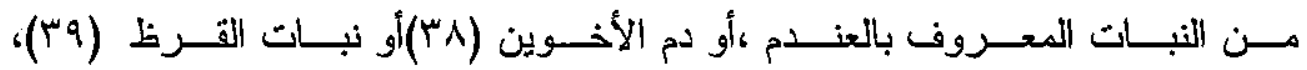

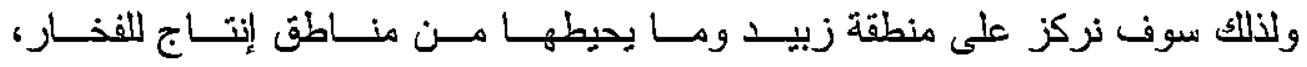

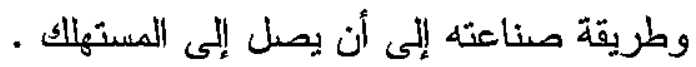

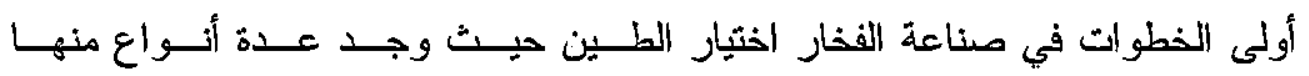

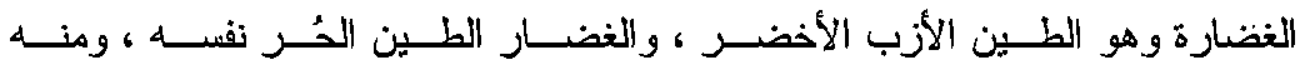

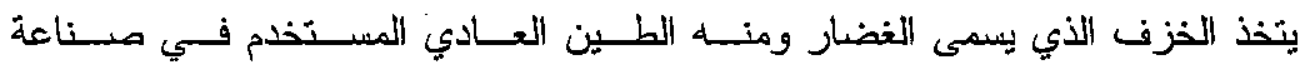

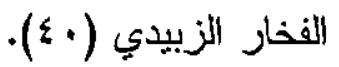


د/ سلطانه ملاح الرويلي بعض من الصرف و الصناعات بزبيث في عهد بني رسول من خلال كتاب ".نور المعارف"

$=$ YYA

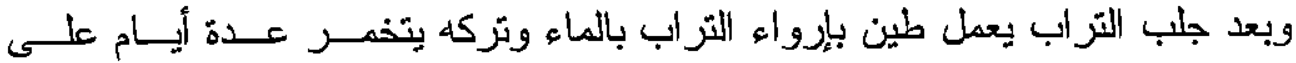

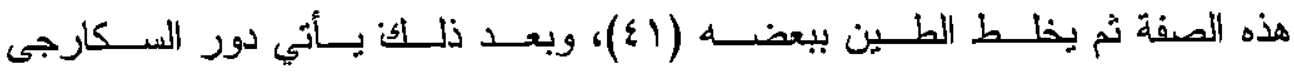

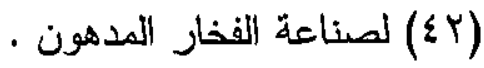

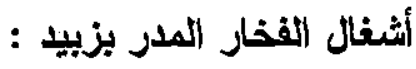

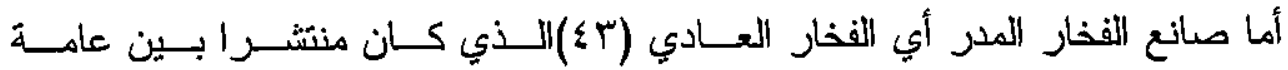

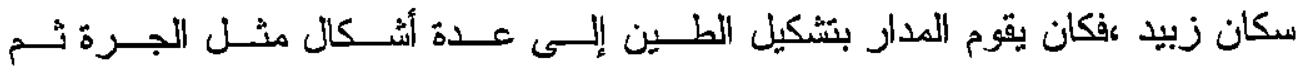

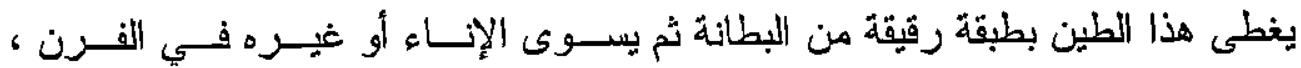

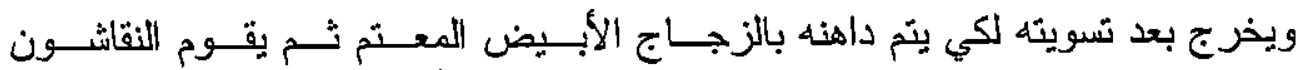

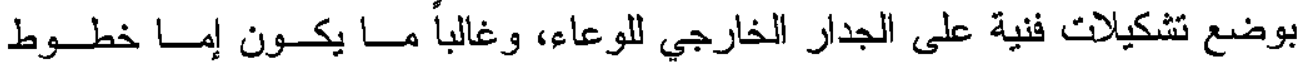

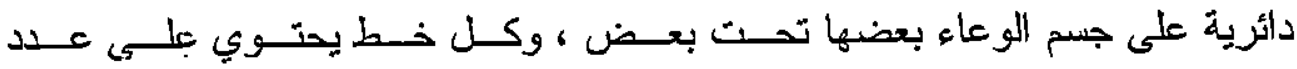

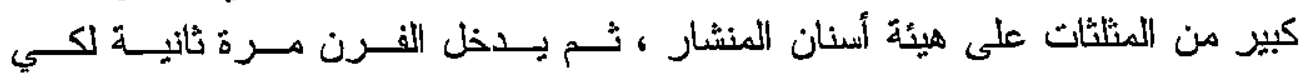
يثبث هذا الادهان ثم يخرجه (ع عـ).

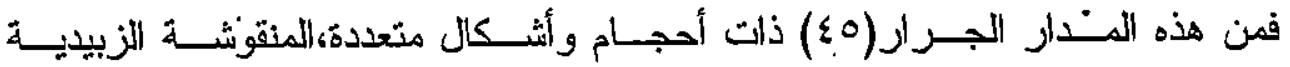

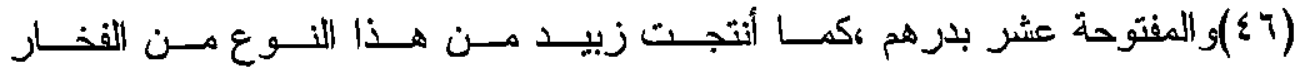

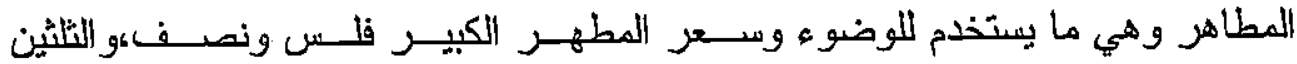

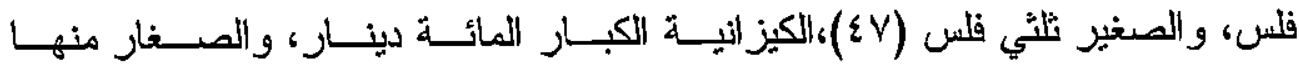

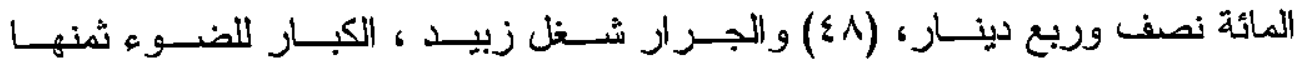

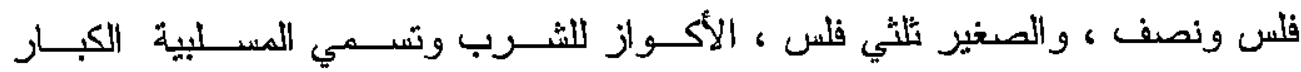

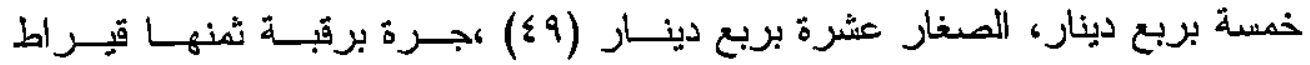

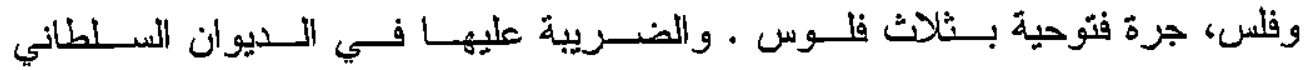

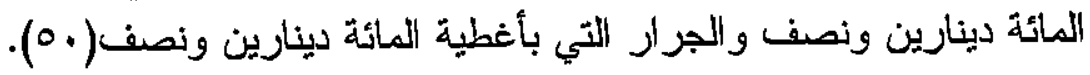

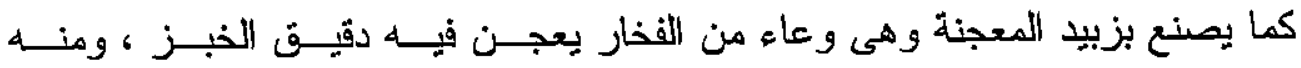

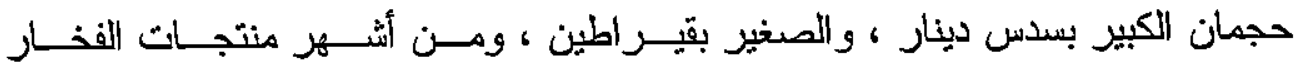

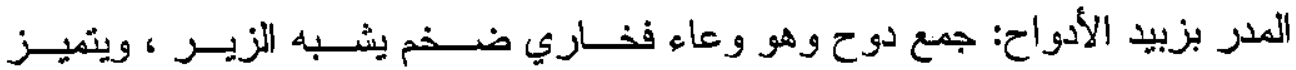


د/ سلطانه ملاح الرويلي بضض من الحرف والصناعات بزبيد في عهد بني رسول

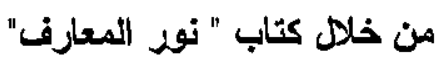

$=$ rrg

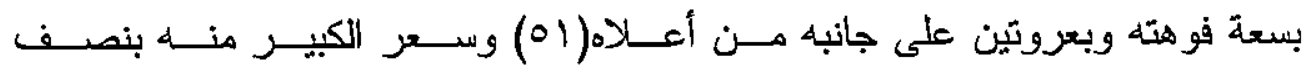

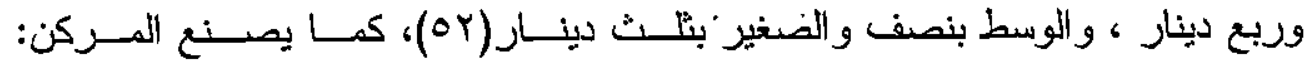

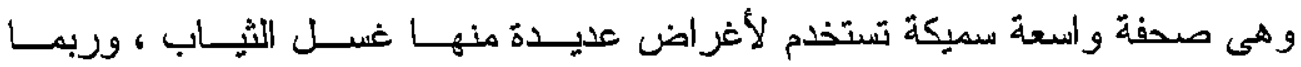

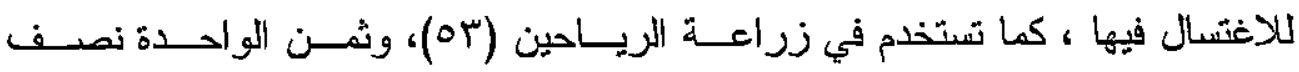

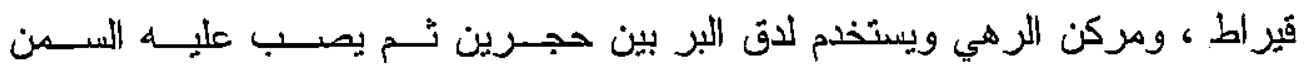

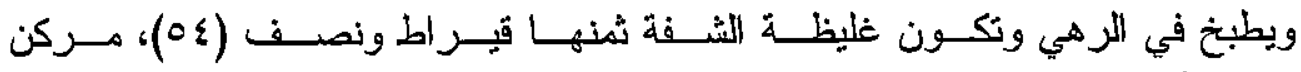

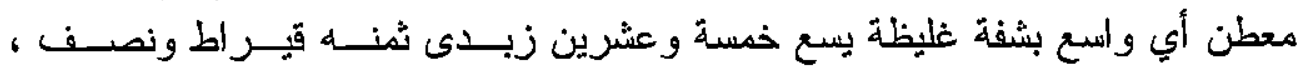

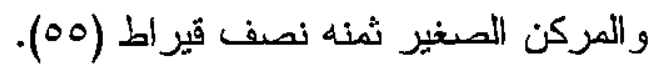

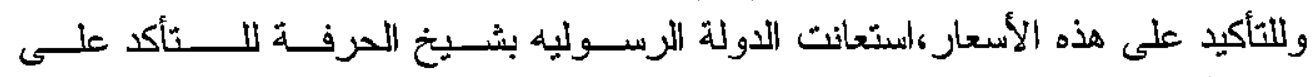

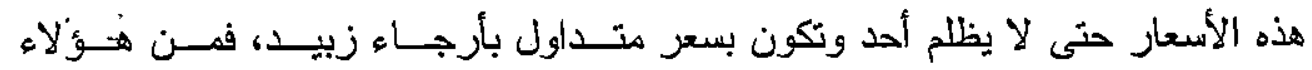

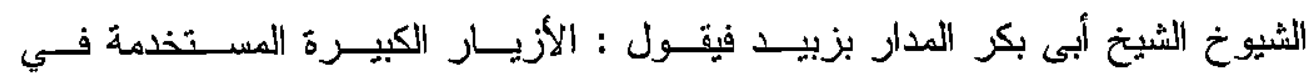

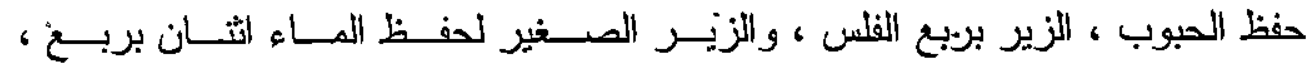

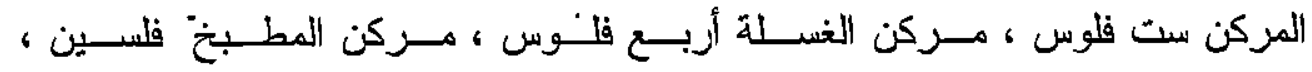

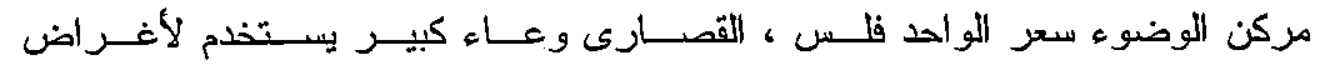

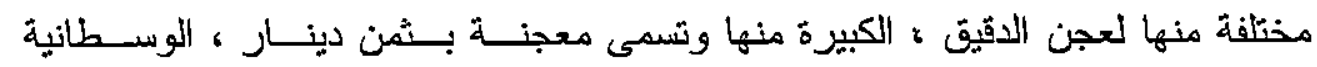

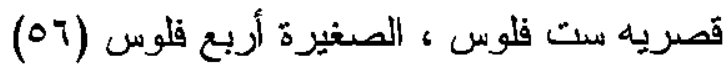

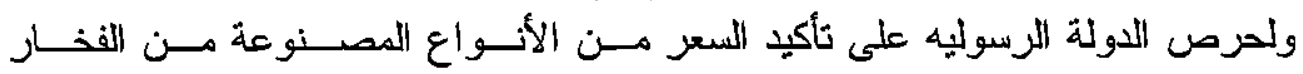

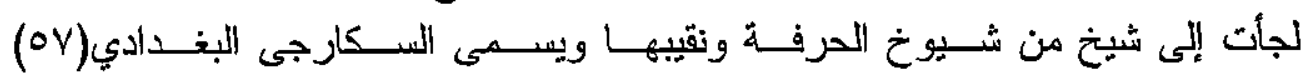
فيقول: فيقات

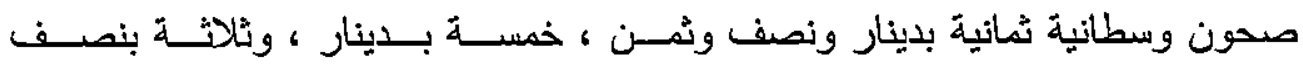

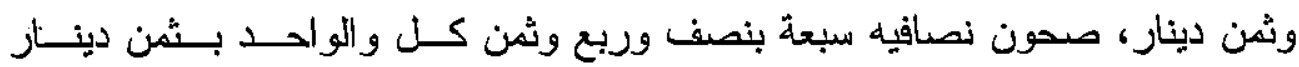

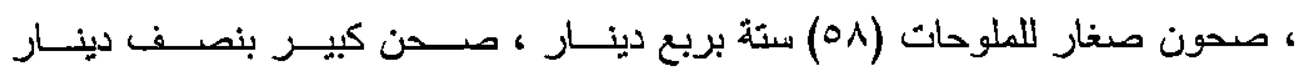

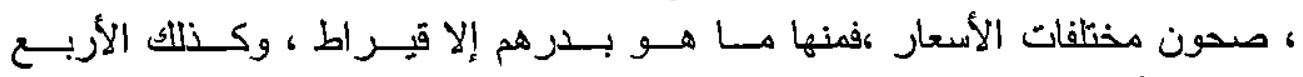

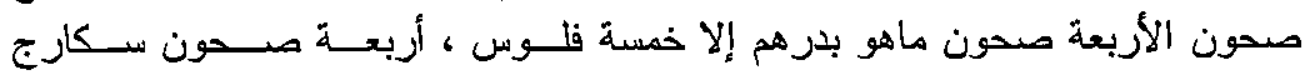


د/ سلطانه ملاح الرويلي بعض من الحرف والصناعات بزبيد في عهل بني رسول من خلال كتاب " نور المعارف"

$=$ Tr. Th:

صغار سبع منها كل واحد بثلاثث فلوس ، سكارج صــار للملوحسات ثمانيــة بربـع

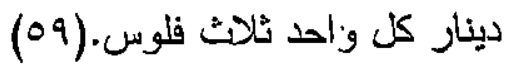

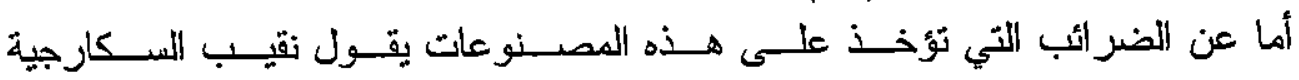

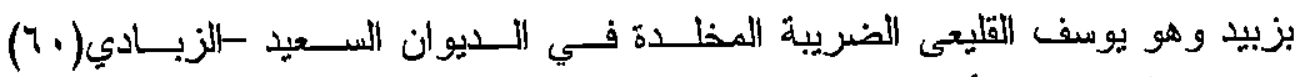

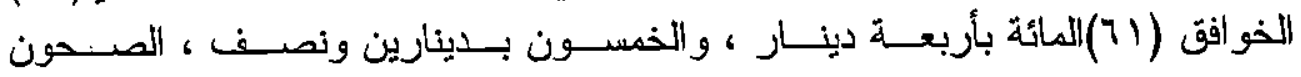

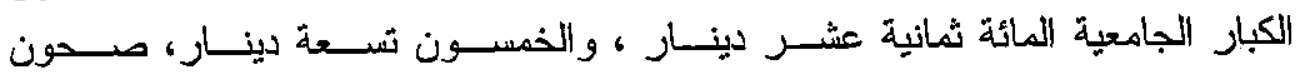

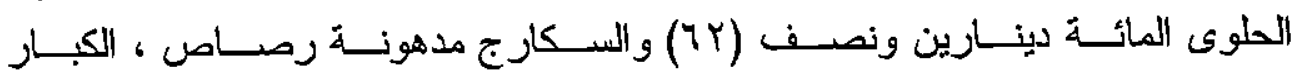

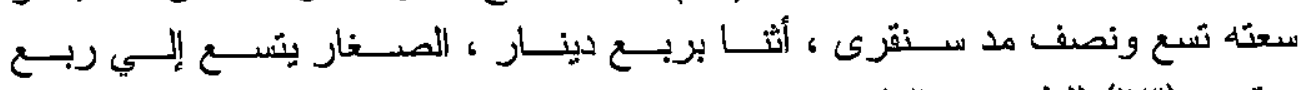

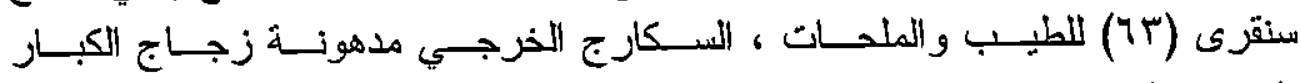

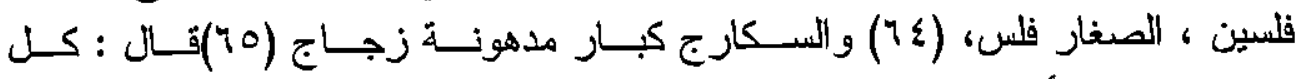

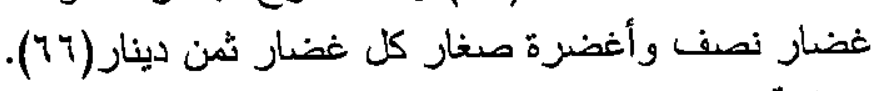

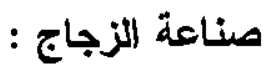

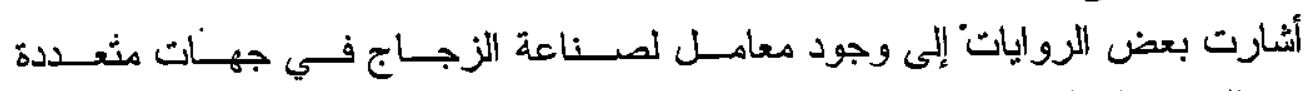

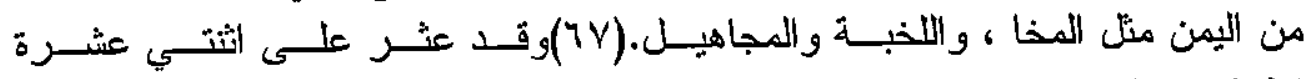

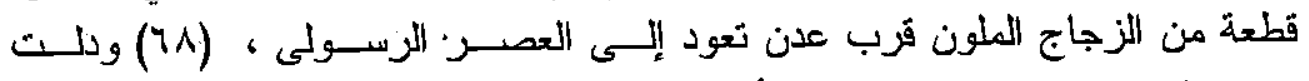

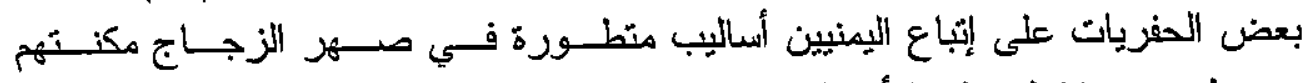

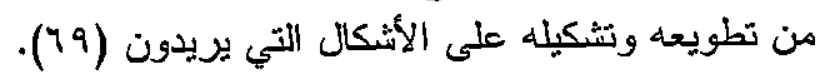

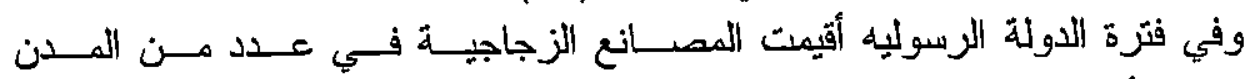

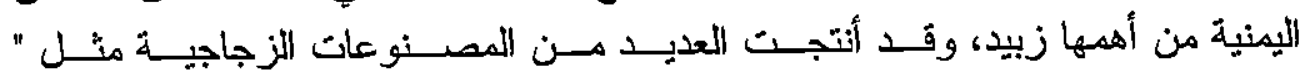

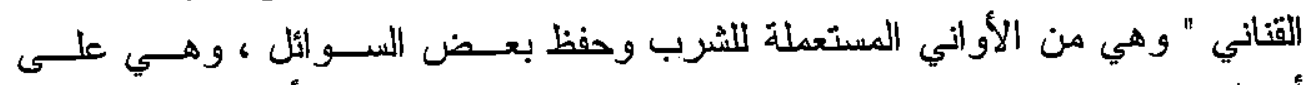

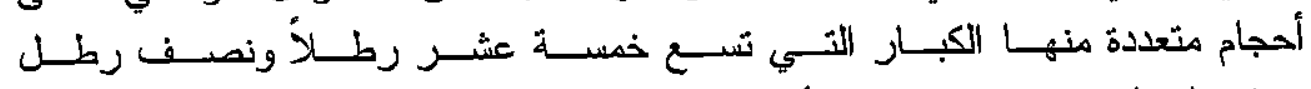

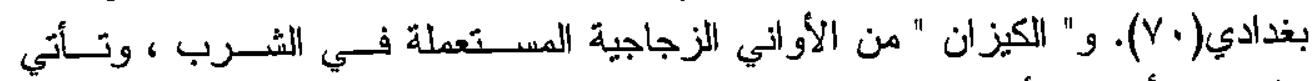

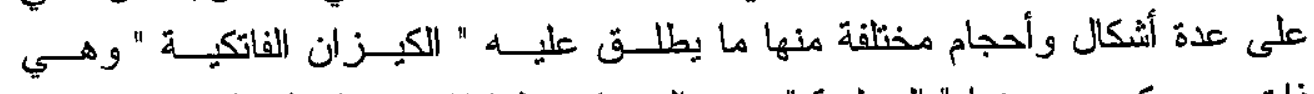

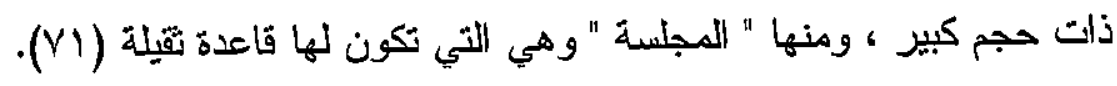


/ / سلطانه ملاح الرويلي بعض من الحرف والصناعات بزبيث في عهد بني رسول

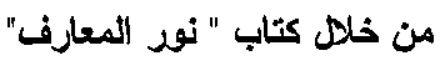

$=$ (TI

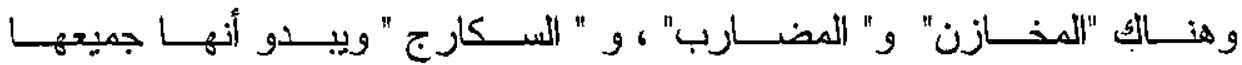

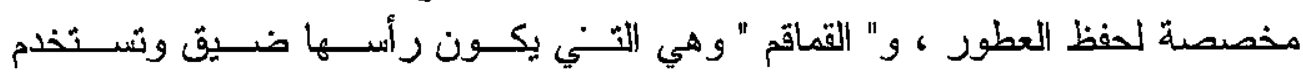

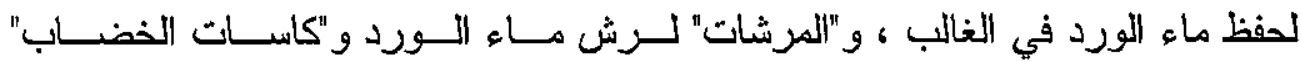

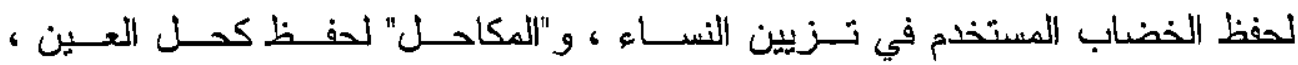
و "المسكيات" لحفظ المسك (VY)

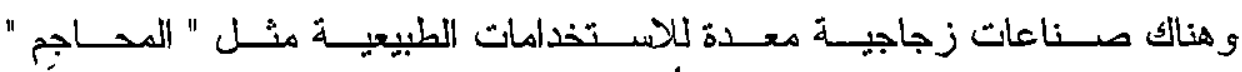

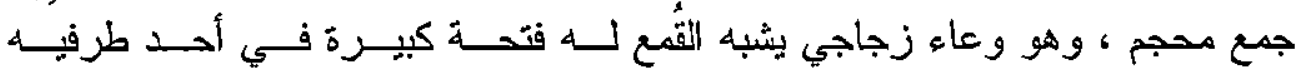

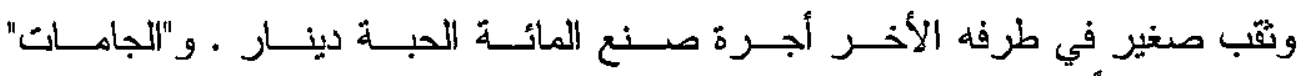

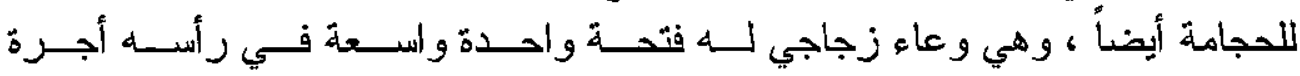

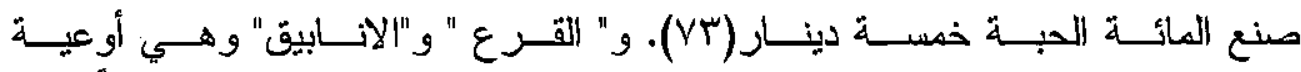

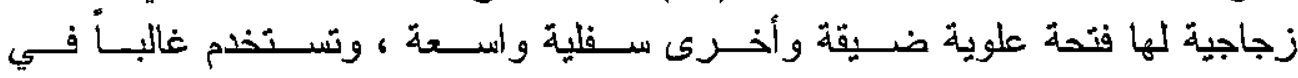

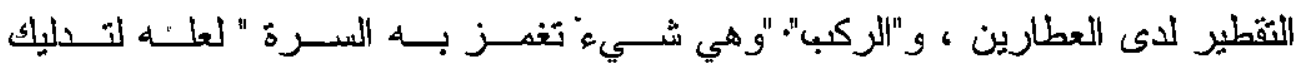

ومن الصناعات الزجاجية ما هو معد لاستخدامه في الإضاءة مثل "القناديل" ، ومنها

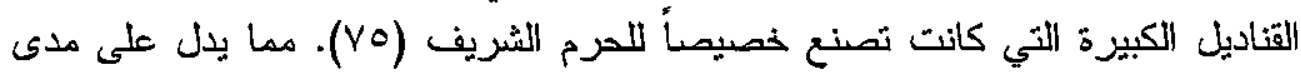

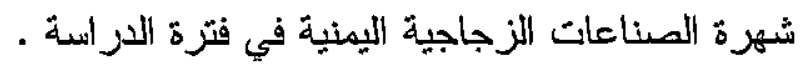

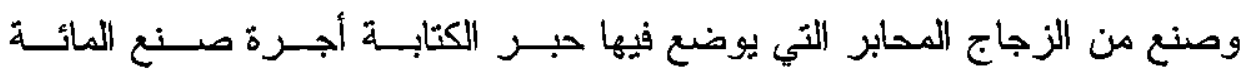

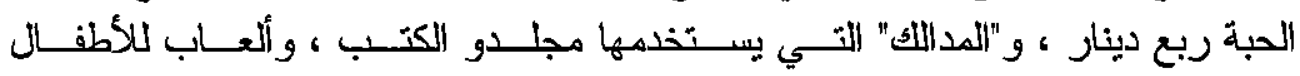

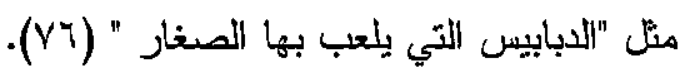

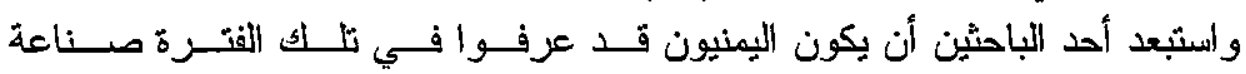

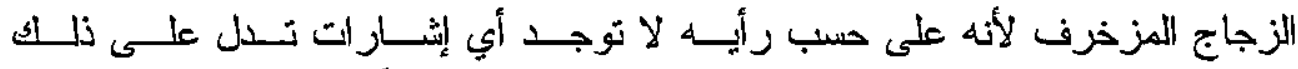

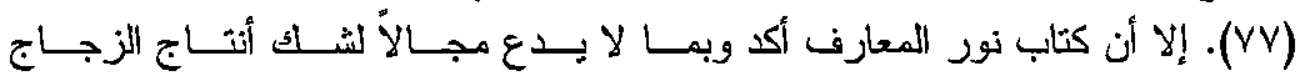

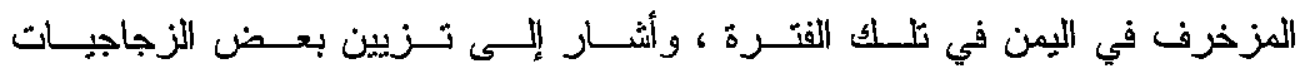

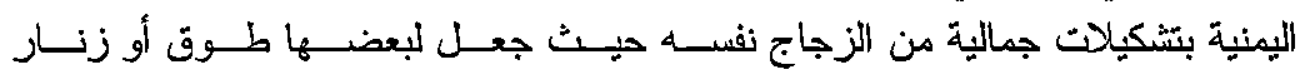


د/ سلطانه ملاح الرويلي بضض من الحرف والصناعات بزبيد في عهد بني ربسول من خلال كتاب " نوز المعارف"

$=$ (TrY

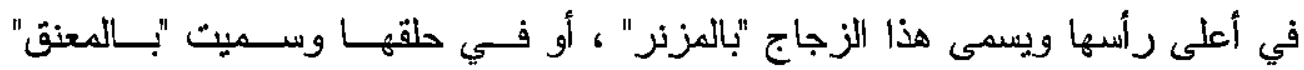

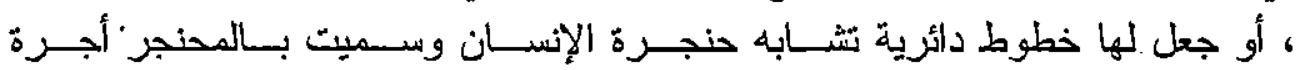

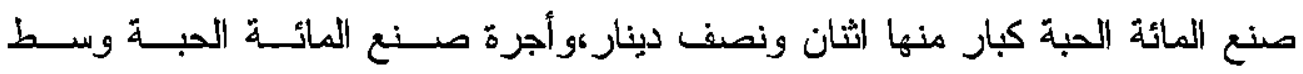

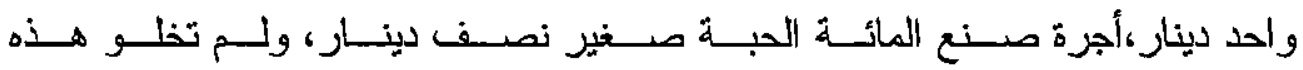

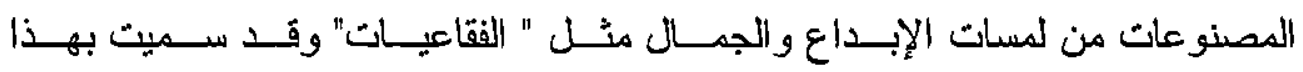

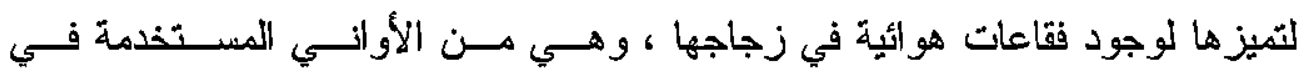

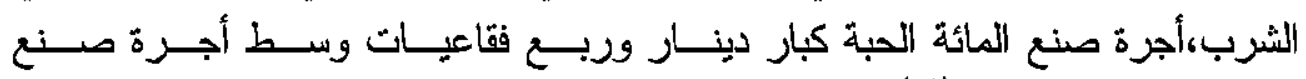
المائة الحبة واحد دينار (Vی)

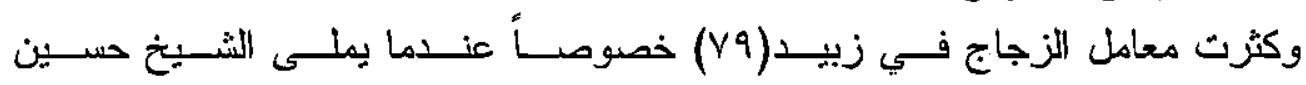

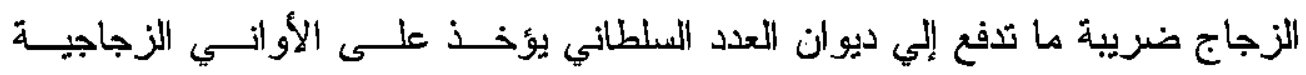

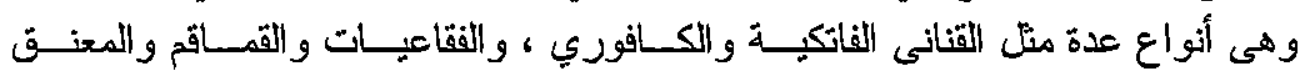

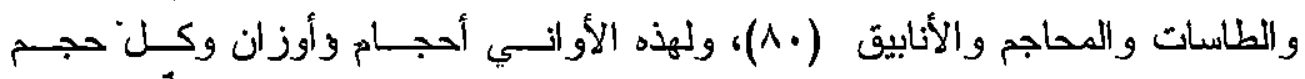

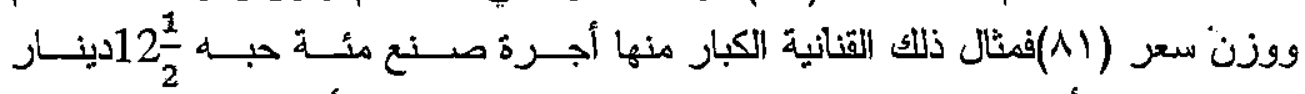

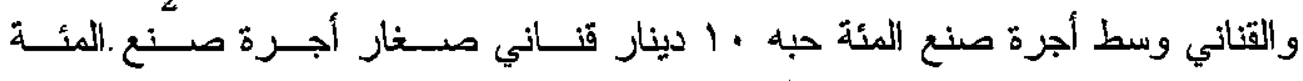

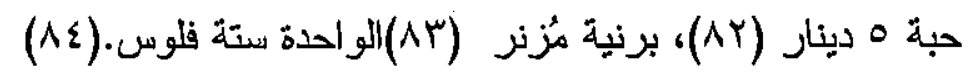

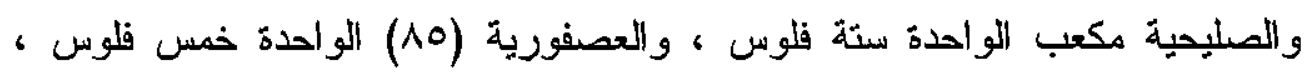

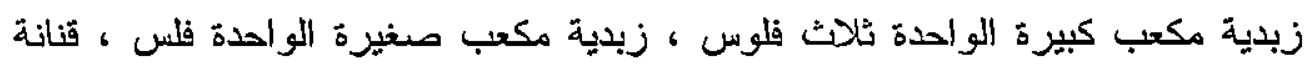

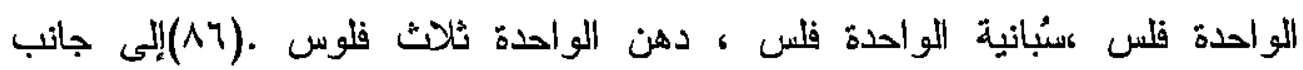

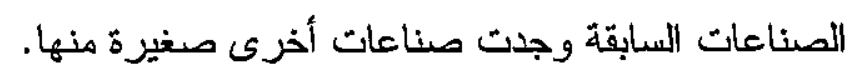

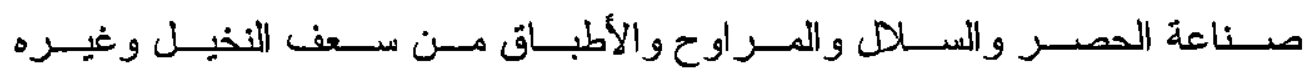
(Av):بزبيد

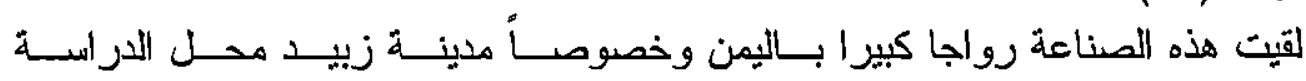

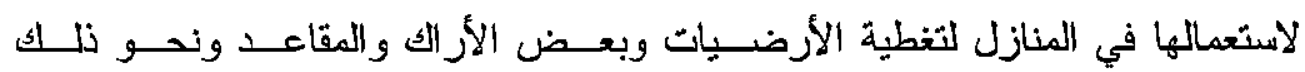

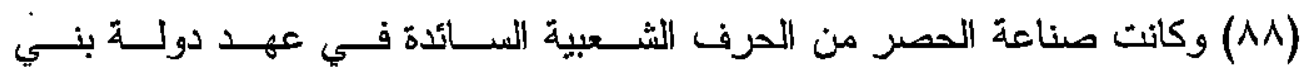


د/ سلطانه ملاح الرويلي بعض من الحرف والصناعات بزييد في عهد بني رسول من خلال كتاب " نور المعارف"

$=\%$ (rrT

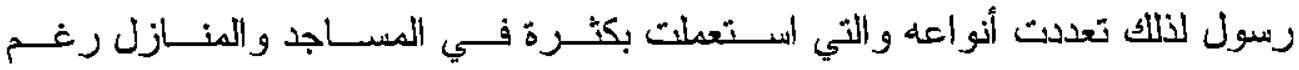

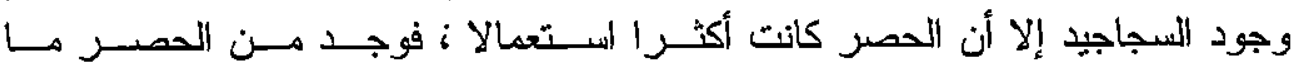

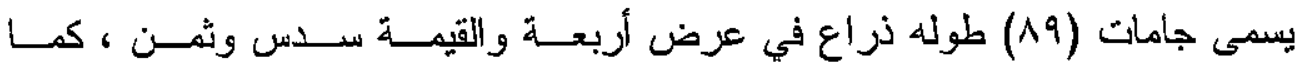

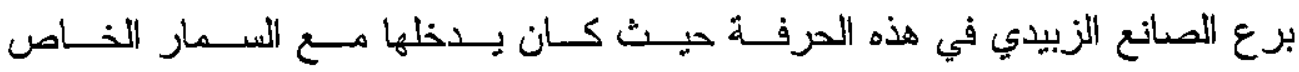

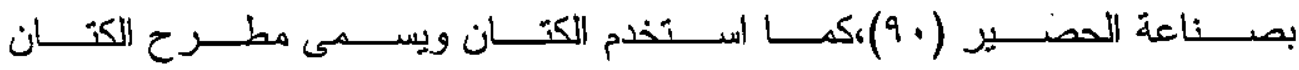

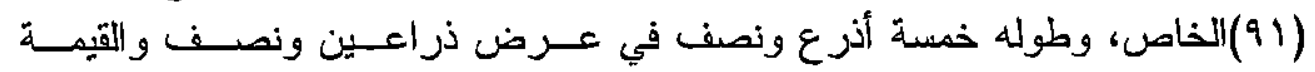

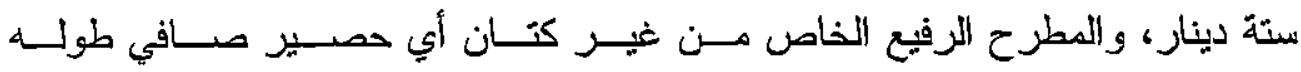

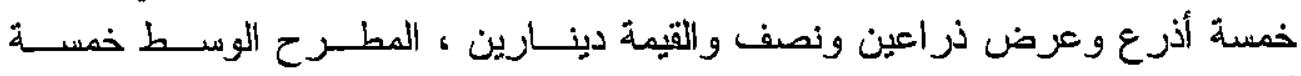

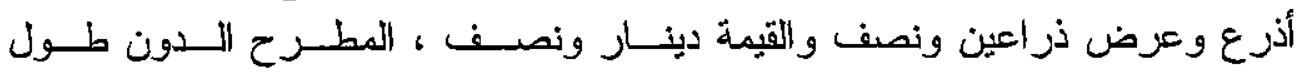

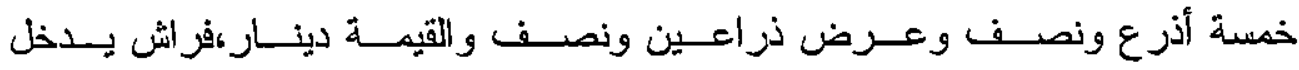

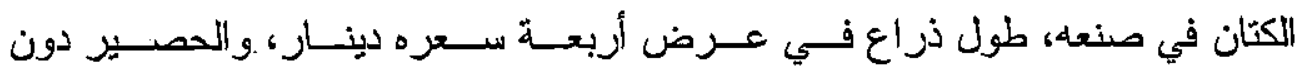

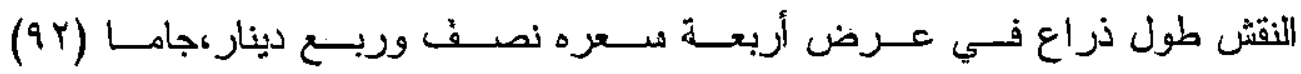

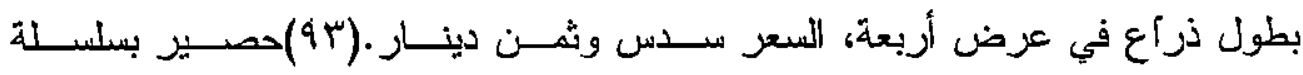

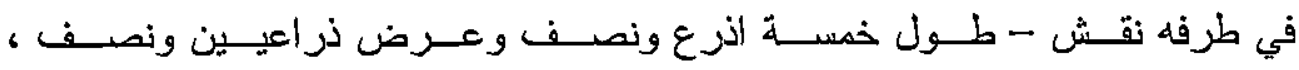

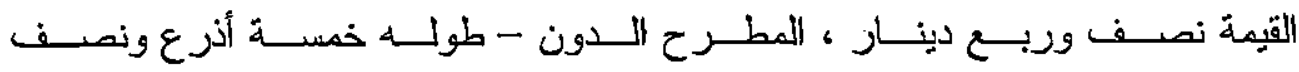

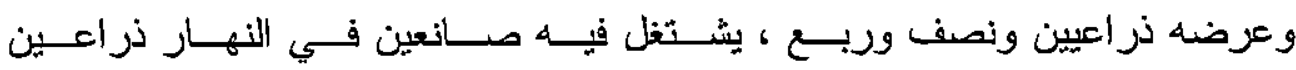

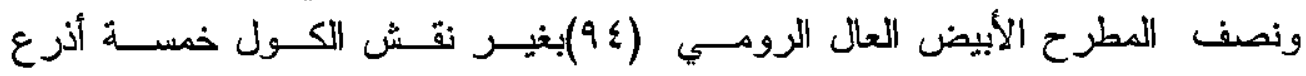

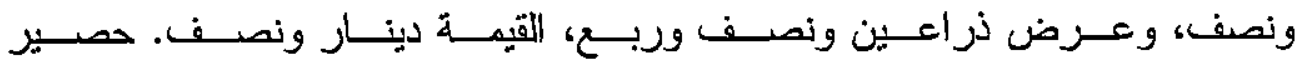

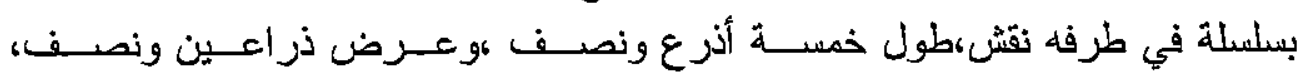

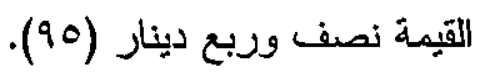

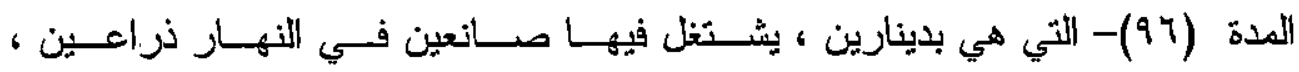

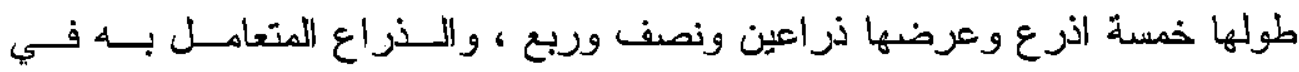

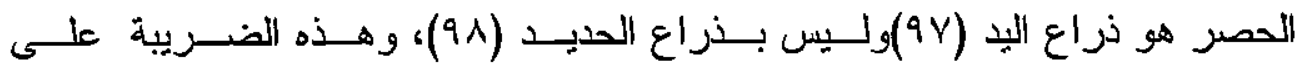


د/ سلطانه ملاح الرويلي بعض من الحرف والصناعات بزبيد في عهل بني رسول

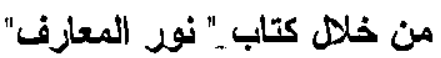

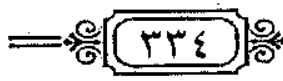

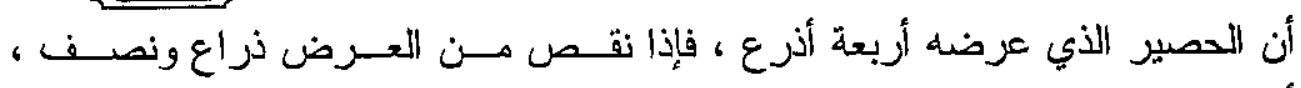

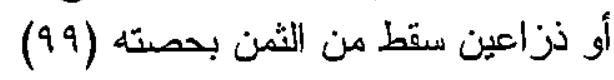
حرفة البناء:

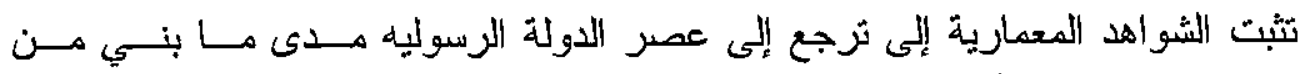

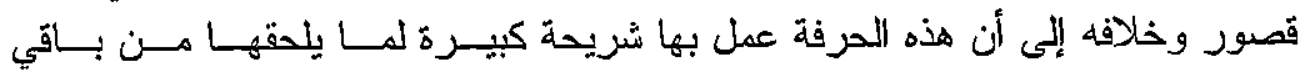

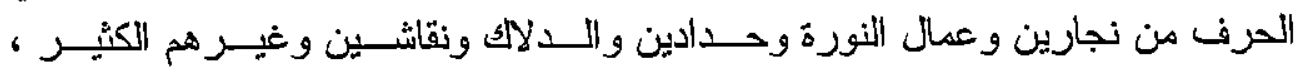

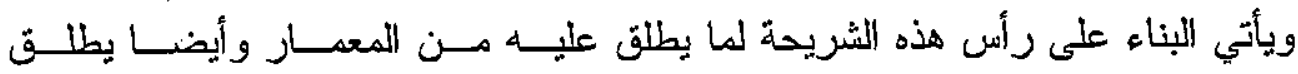
على الأستاذ منل عتيق وهو من كبار البنائين (...

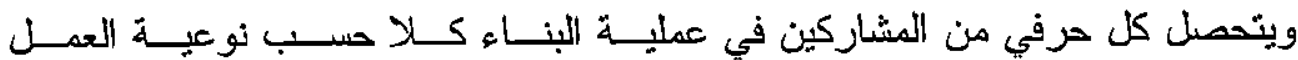

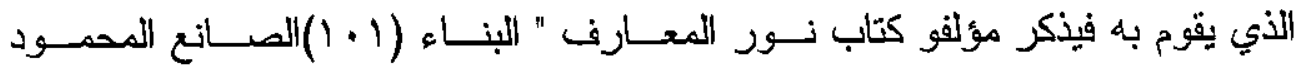

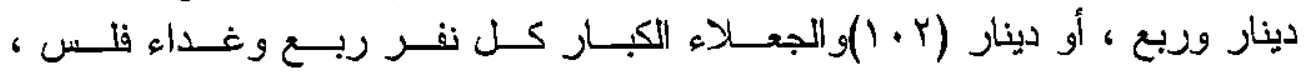

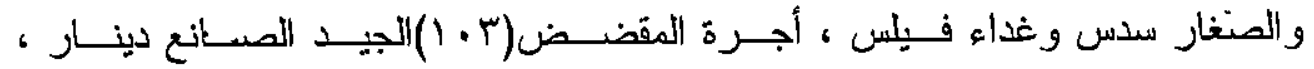

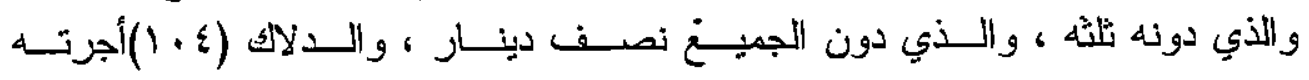

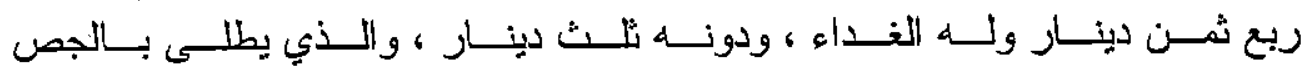

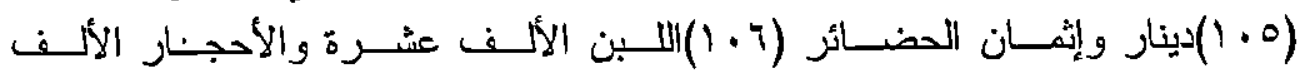

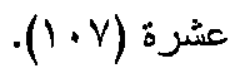
و الأضبار الألف خمسة ، والجيد والردى سواء في الأضبار والحجار ، وأجزة النجار

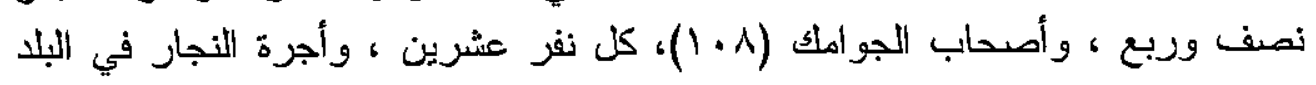

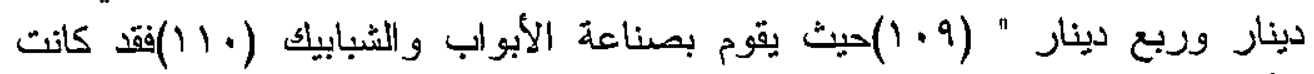
الأبو اب ترنكز على أرجل وتسمى أرجل الباب(11)

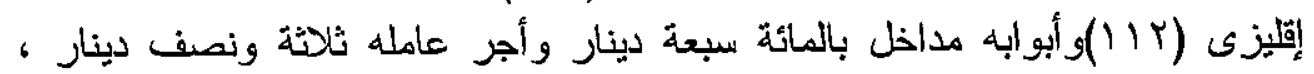

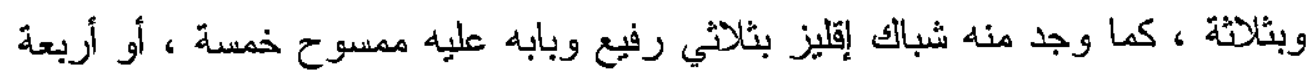

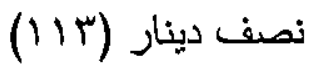


د/ سلطانه ملاح الرويلي بعض من الحرفـ والصناعات بزبيد في عهد بني رسول من خلال كتاب " نور المعارف"

$=$ rro

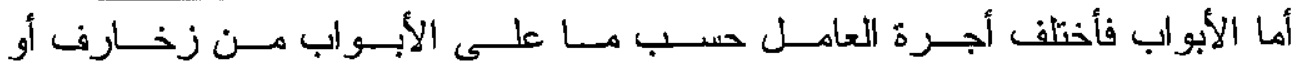

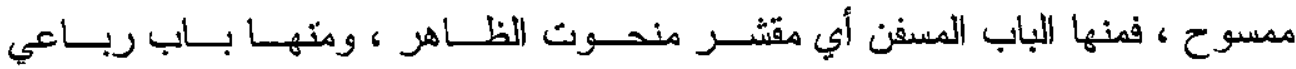

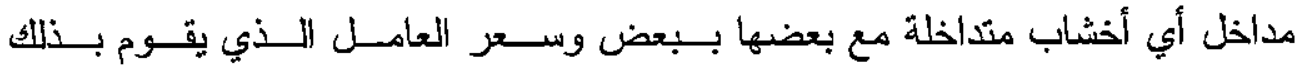

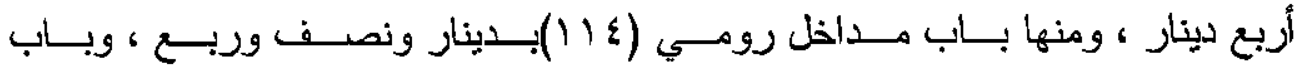

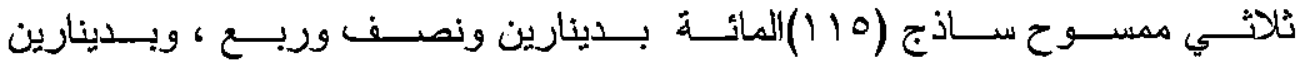

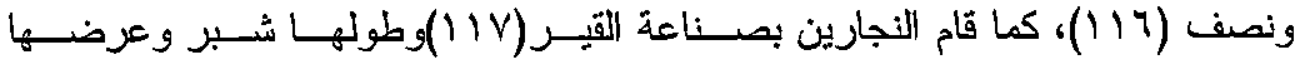
أصبعين الألف منها بدينارين.(11)

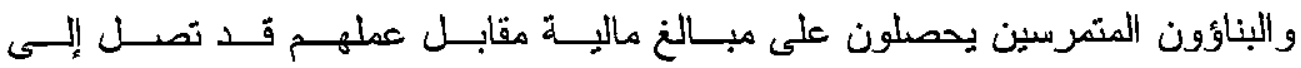

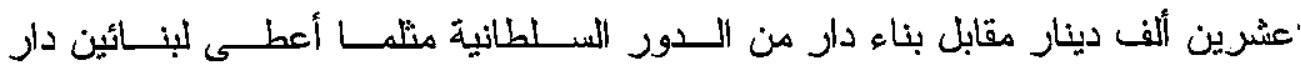

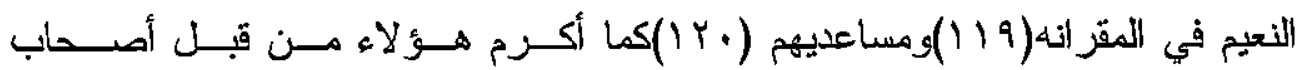

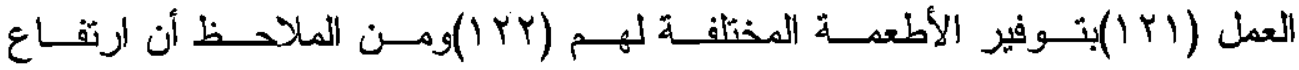

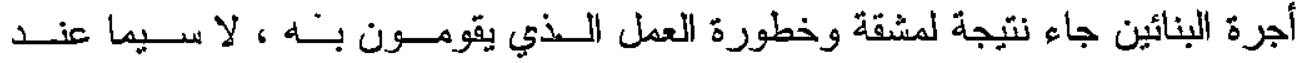

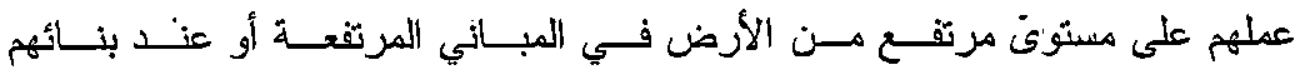

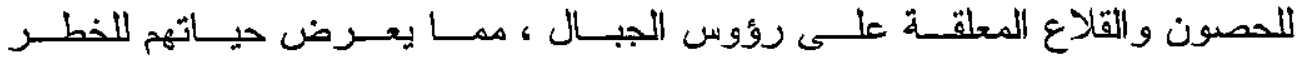

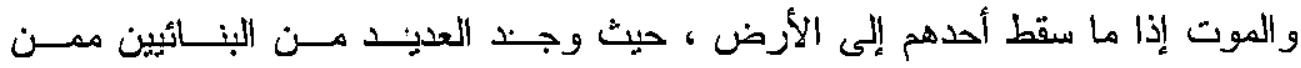

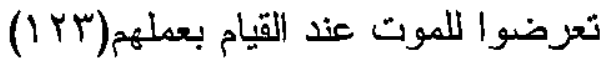

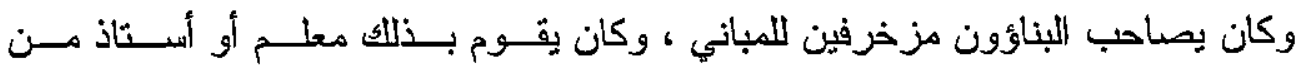

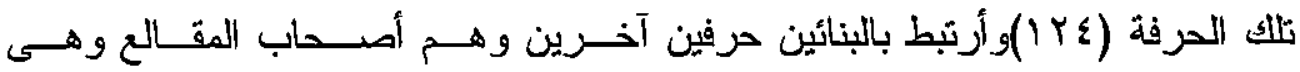

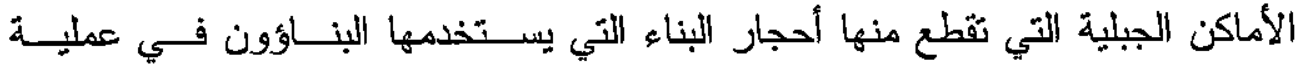

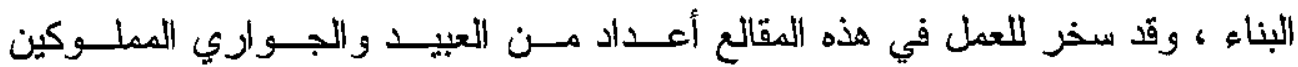
لأصحاب المقالع الأين انتشروا في بعض الماء المناطق الجبلية.(1Y00)

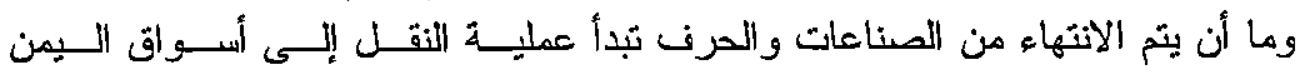

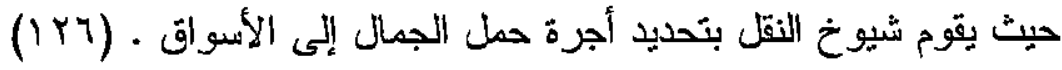


د/ سلطانه ملاح الرويلي بعض من الحرف والصناعات بزبيد في عهد بني رسول

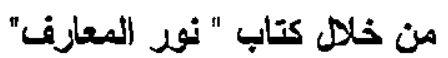

$=$ (19.

$$
\begin{aligned}
& \text { المصادر والمراجع } \\
& \text { أولأ: المصادر. } \\
& \text { ا-برأن كريم: }
\end{aligned}
$$

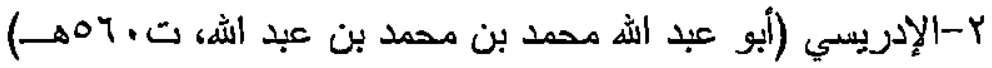

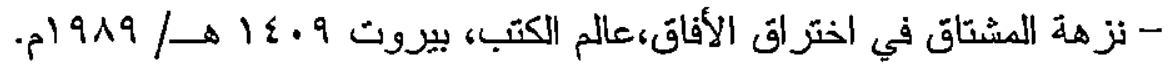
r-الأزهري: - بزهي

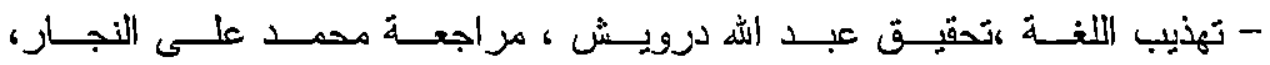

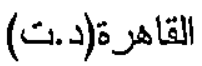

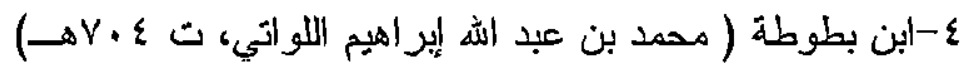

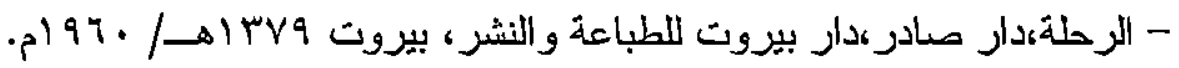

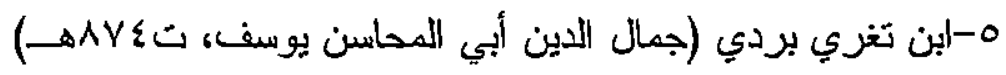

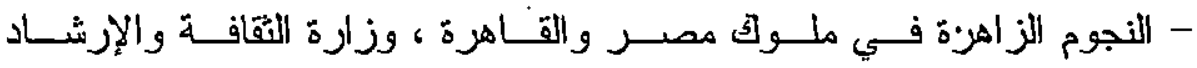
القومي، مصر (دكت).

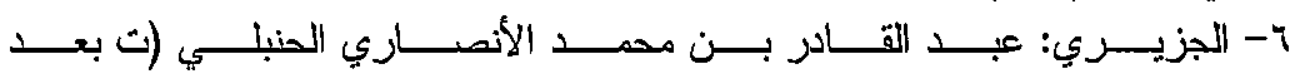
$.(0) 071 /-9974$

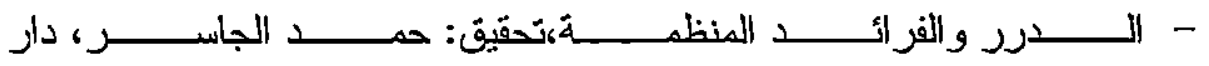

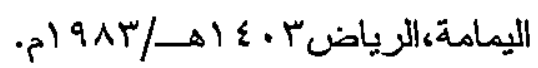

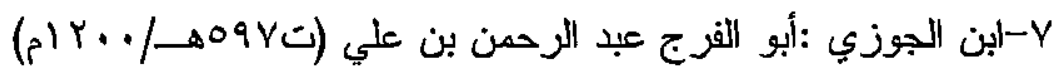

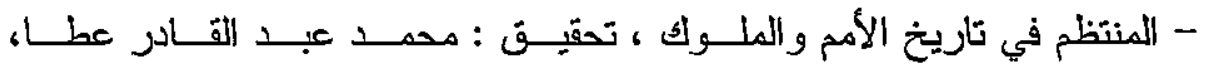

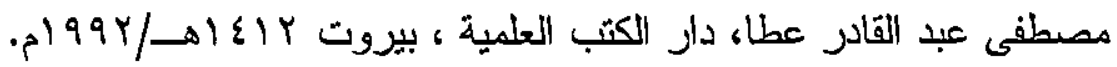

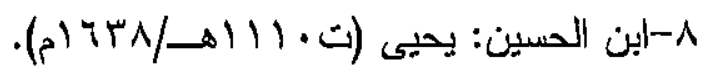

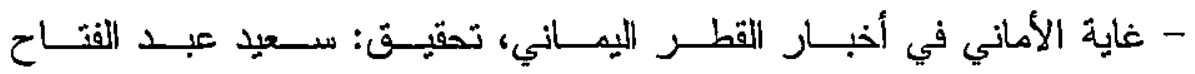

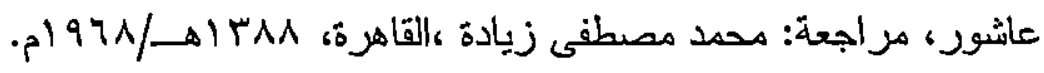

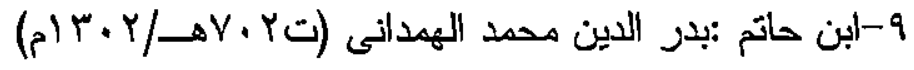


/ / سلطانه ملاح الرويلي بعض من الحرف والصناعات بزبيد في عهد بني رسول

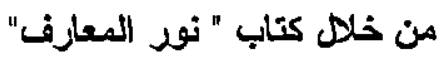

$=$ (1)

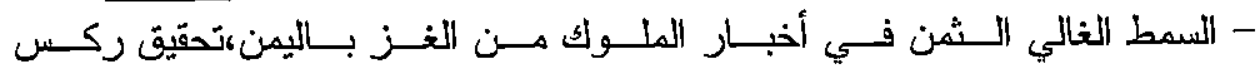

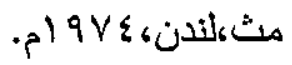

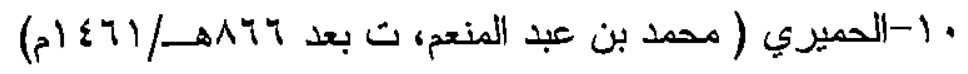

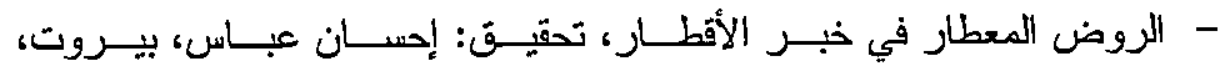

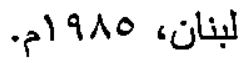

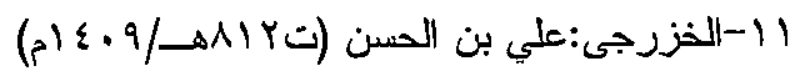

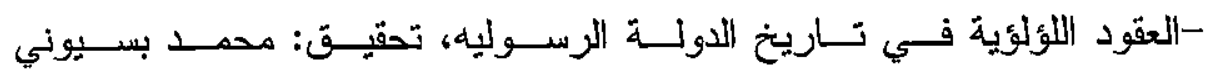

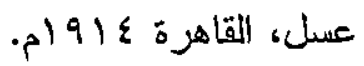

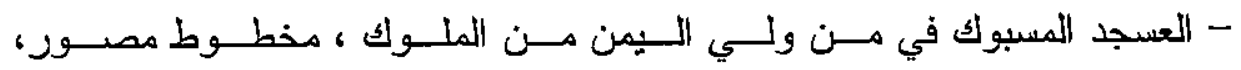

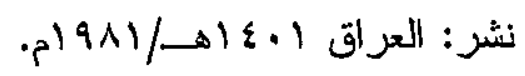

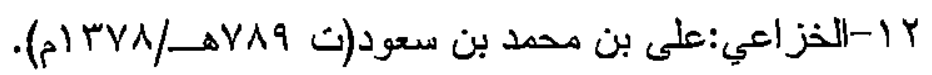

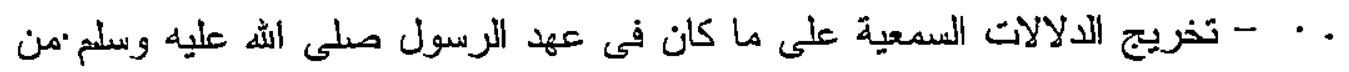

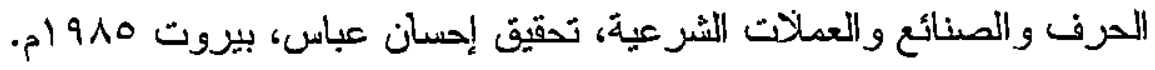

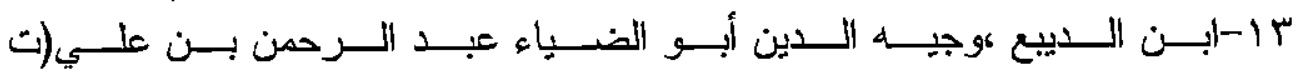
(م) م)

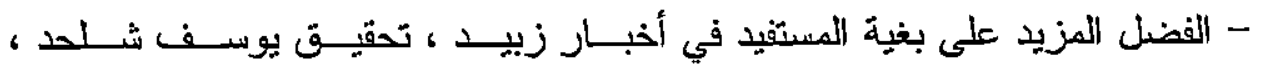

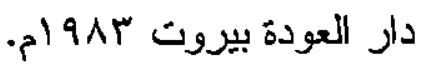

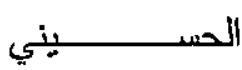

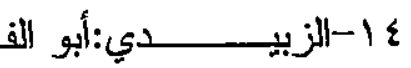

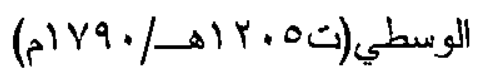

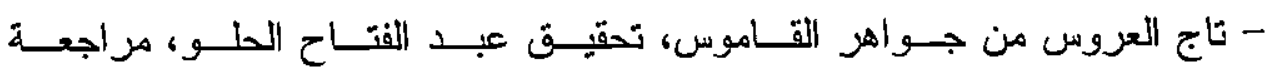

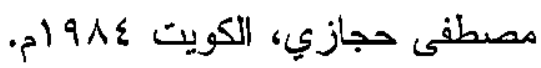

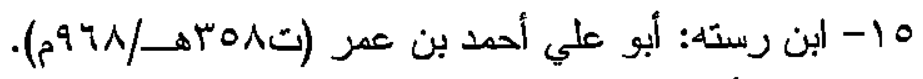

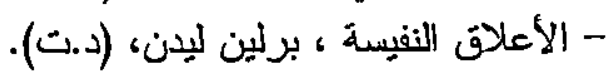

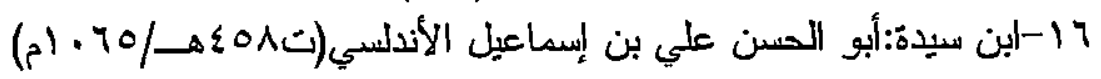


د/ سلطانه ملاح الرويلي بعض من الحرف والصناعات بزبيد في عهل بني رسول من خلا كتاب " نور المعارف"

$=$ TIT

- المخصص، بيروت، (د.ت)

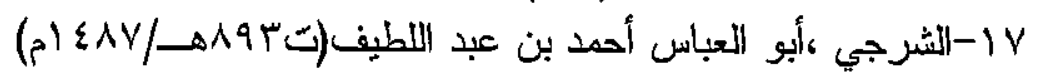

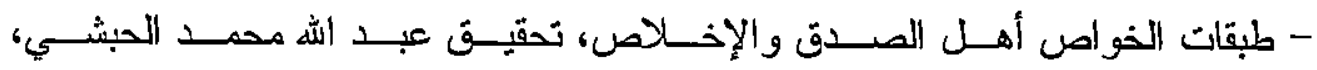

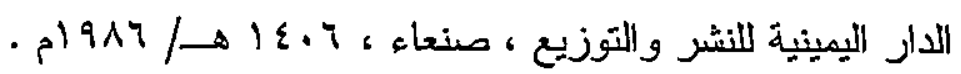

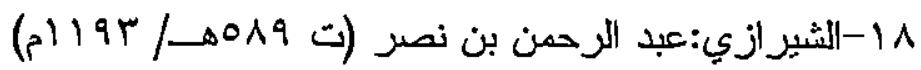

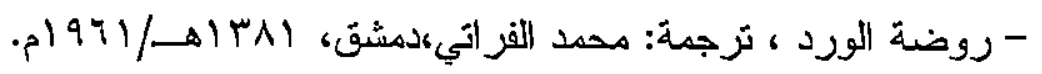

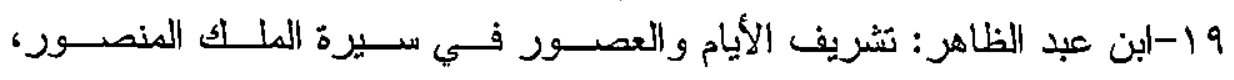

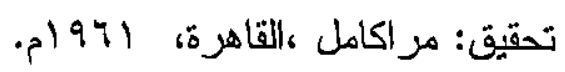

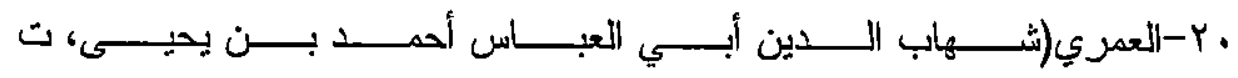
(a) $r \leqslant q / \rightarrow \gamma \leqslant q$

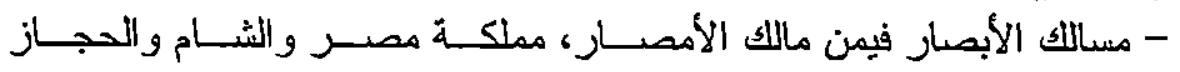

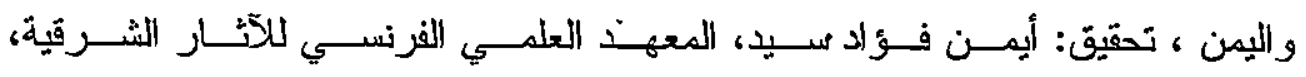

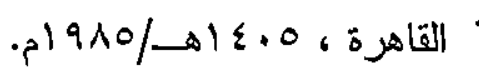

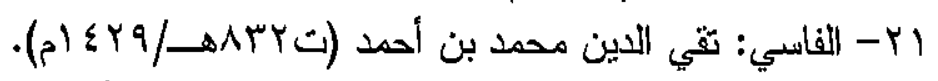

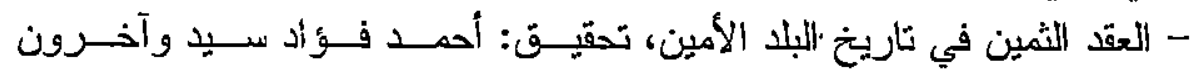

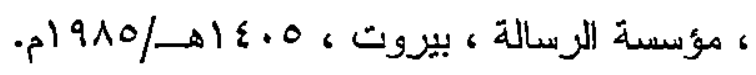

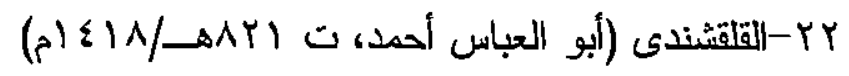

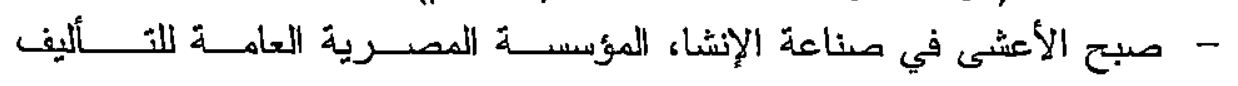

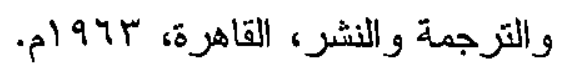

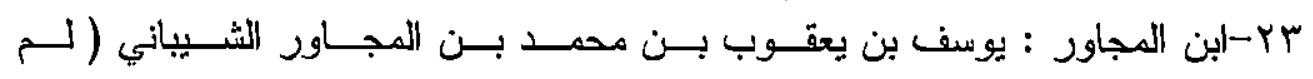
تعزف سنة وفاته )

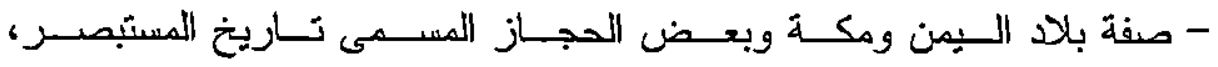

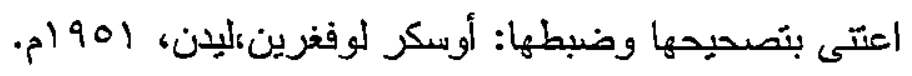

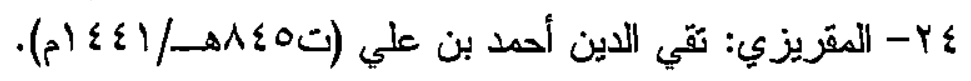


د/ سلطاته ملاح الرويلي بعض من الحرف والصناعات بزبيد في عهد بني رسول

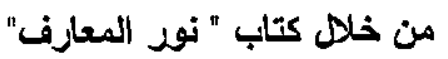

$=$ (TTM

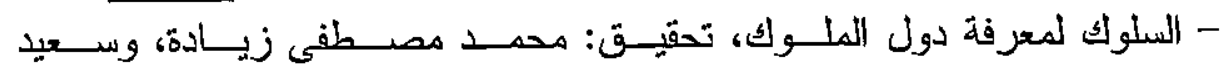

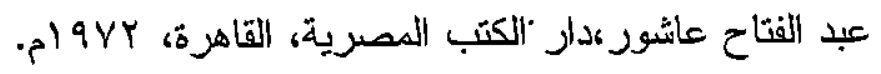

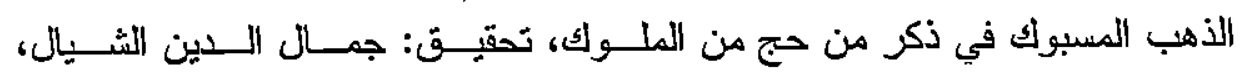

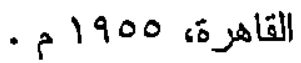

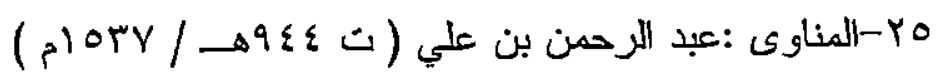

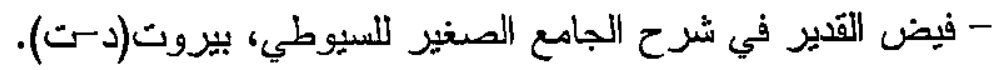
بץ-مجهول:معاصر للدولة الرسوليه.

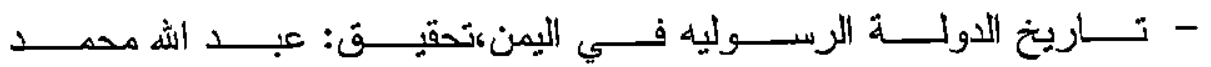

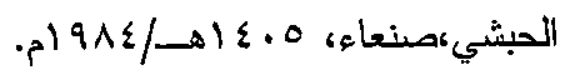

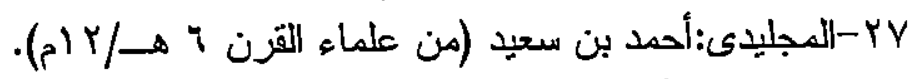

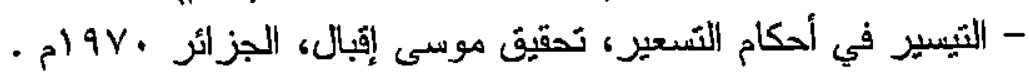

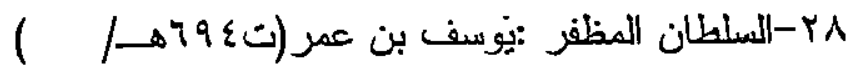

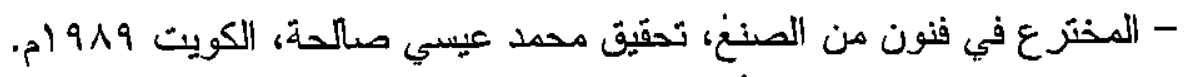

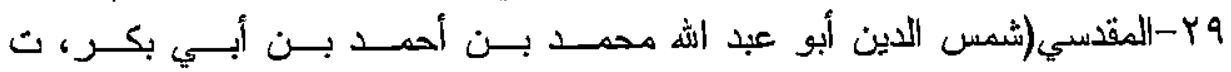
(م999/- $\rightarrow$ (r).

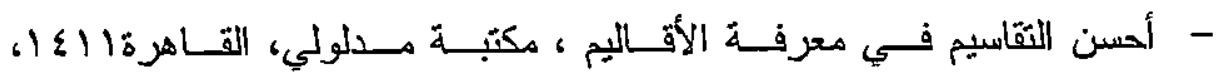
هـ

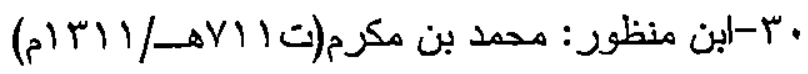

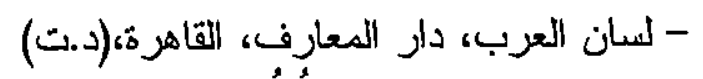

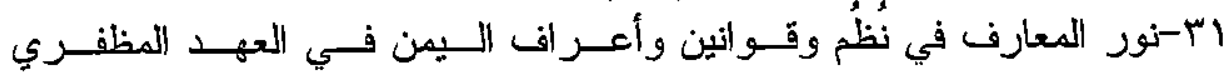

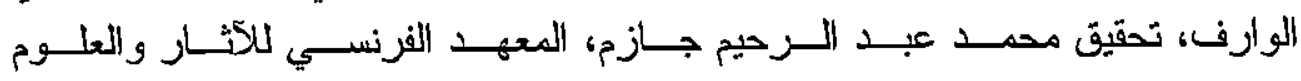

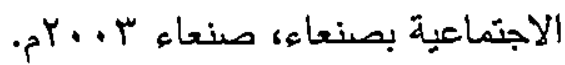
Yr-الهمدانى (الحسين بن أحمد، ت 
د/ سلطانه ملاح الرويلي بعض من الحرف و الصناعات بزبيد في عهل بني رسول من خلال كتاب " نور المعارف"

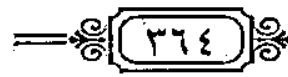

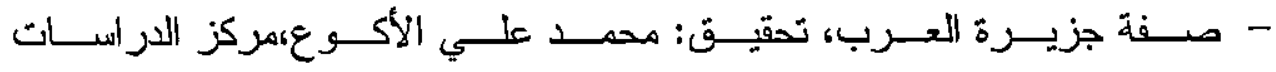

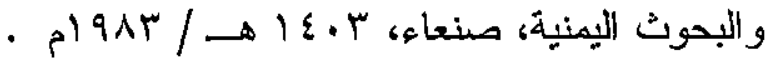

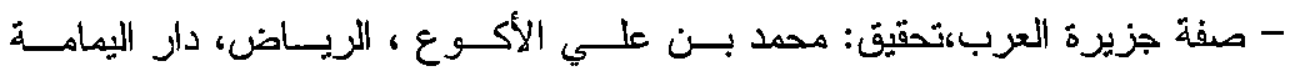

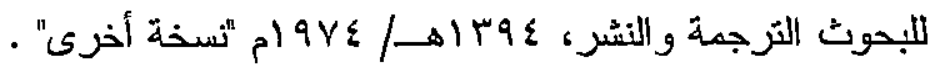

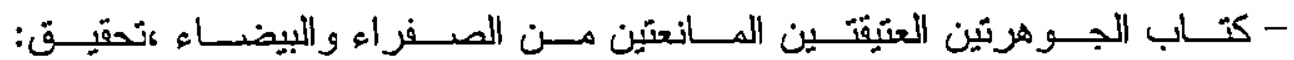

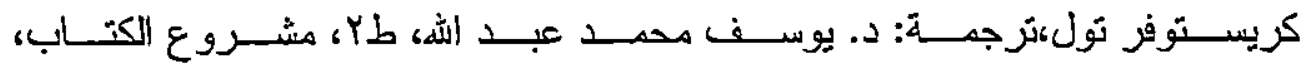
صنعاء، 910 ام

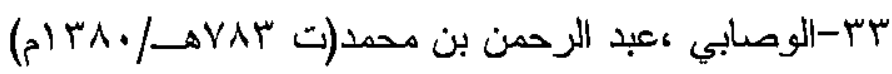

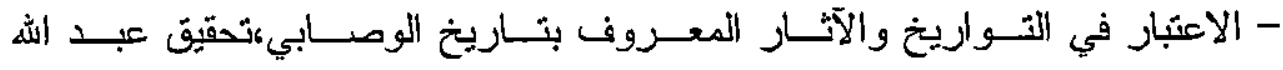
الحبشي صنعاء 979

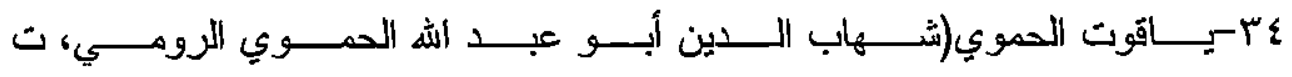
(مIYYN/DTYY

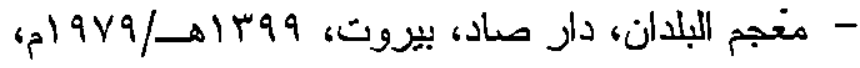
المالجراجيم أحمد المقحفي:

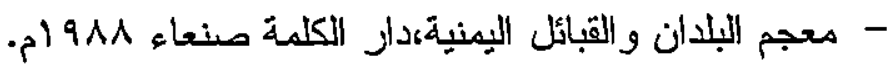
ب- بأسامة أحمد حماد:

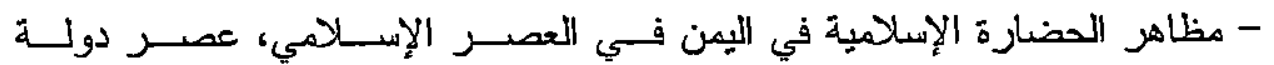

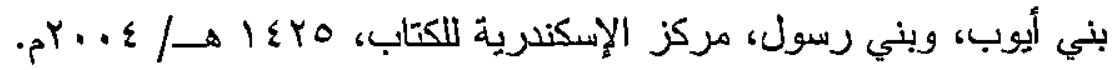

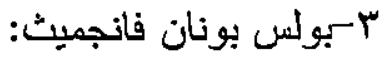

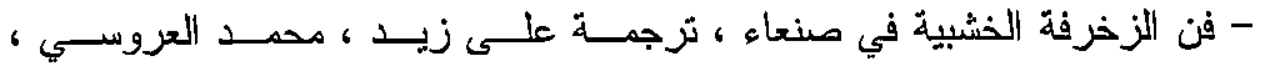

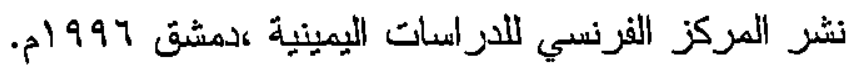

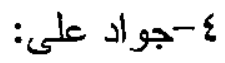
- المفصل في تاريخ العرب قبل الإسلام، بغداد 1ولام. 
/ / سلطانه ملاح الرويلي بعض من الحرف والصناعات بزيبد في عهد بني رسول

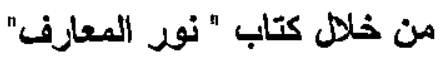

$=$ rro

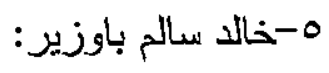

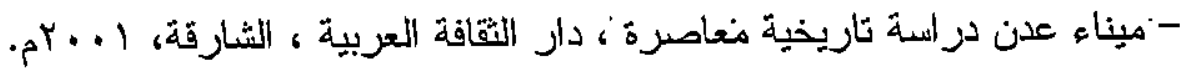

$$
\text { 4- ب- ربيع حامد خليفة: }
$$

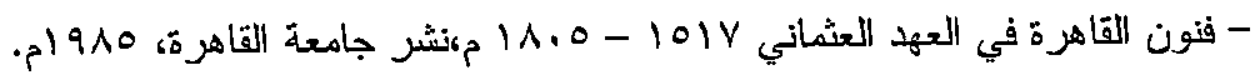

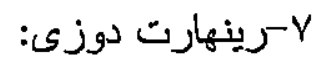

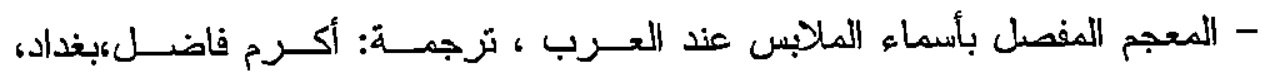

. $19 \times 1 /-81+91$

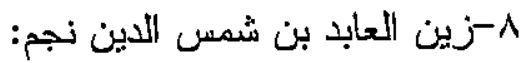

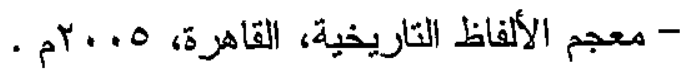

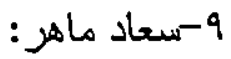

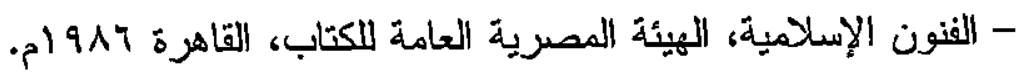
. ا-صباح إير الهيم سعيد الشيخلي:

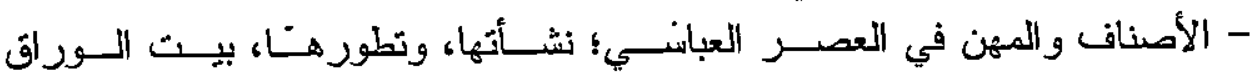

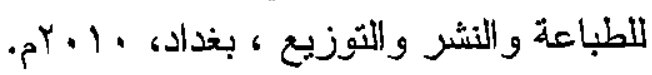
||-طه حسين هذيل:

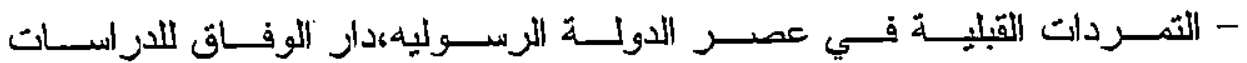

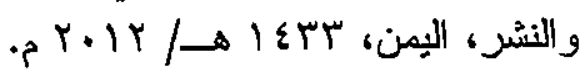

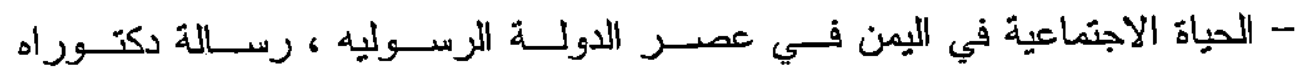

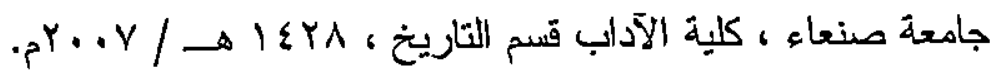
rا-ظاهر خير الله الشويرى:

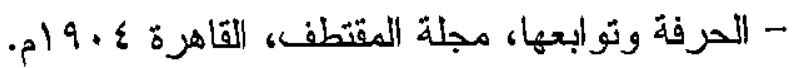
rا-عبد الناصر ياسين:

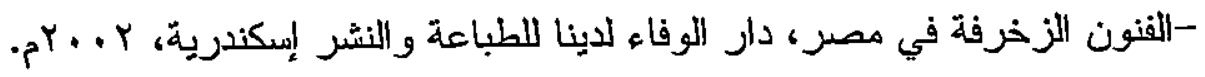
ع ا-عبد الله محمد السيف: 
د/ سلطانه ملاح الرويلي بعض من الحرف والصناعات بزبيد في عهد بني رسول من خلا كتاب " نوم المعارف"

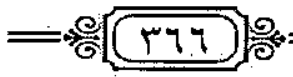

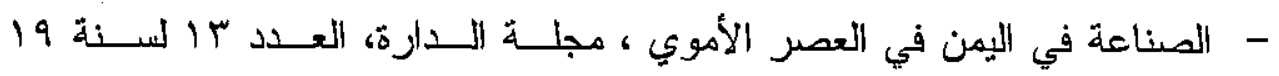

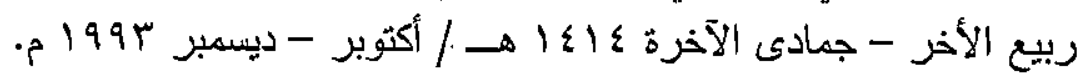
10-عبد المنعم عبد الحميد سلطان:

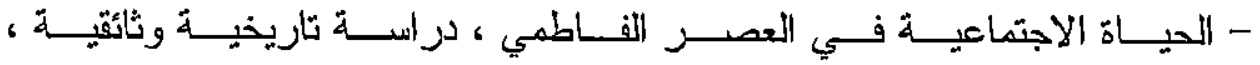

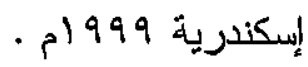
1 ا-عطا الله بن حمود بن مزيد الرويلي:

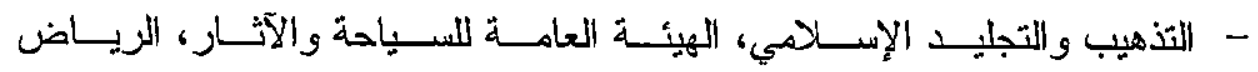
.

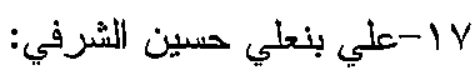

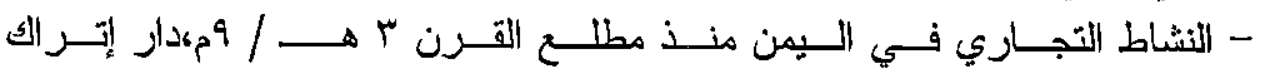

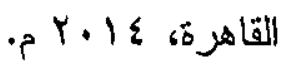
1 1-فالتز هانتس:

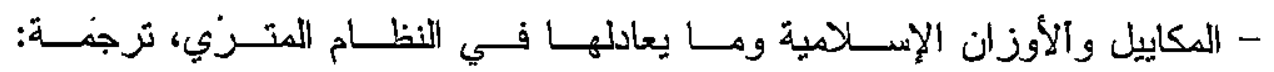

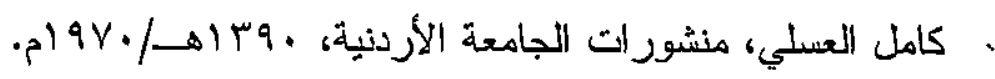

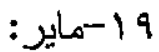

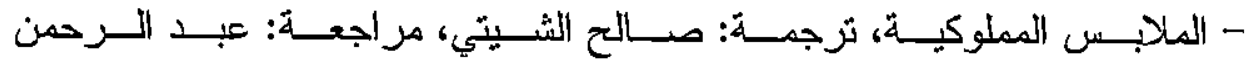

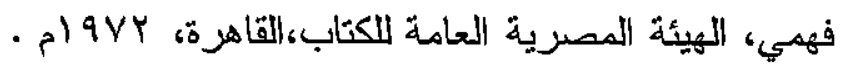

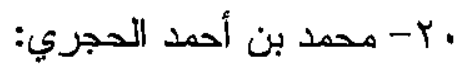

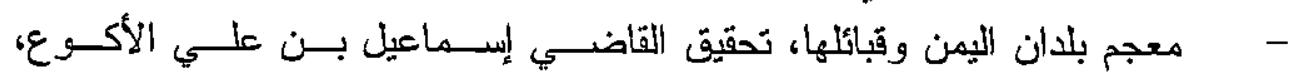

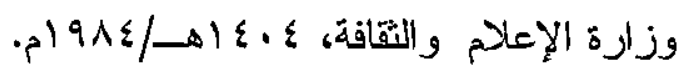

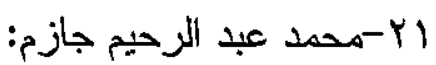

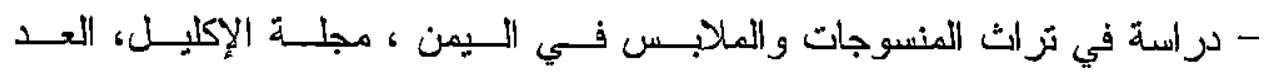

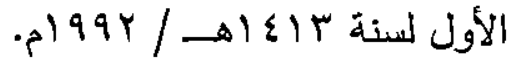
Y ب-محمد بن أحمد الحجري: 
/ / سلطانه ملاح الزويلي بعض من الحرف والصناعات بزبيد في عهل بني رسول من خلا كتاب " نور المعارف"

$=$ rqV

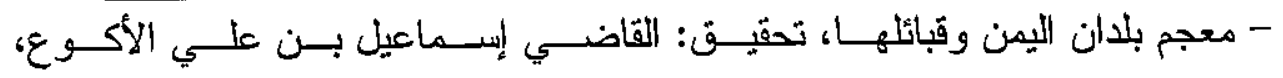

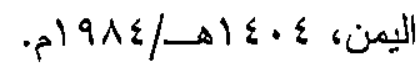
بr-محمد عبد العال أحمد:

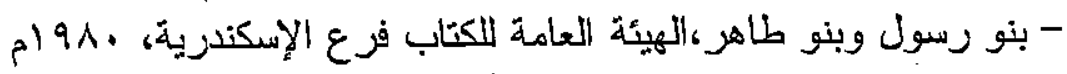
ع צ-مصطفى محمد سعيد الشهابي:

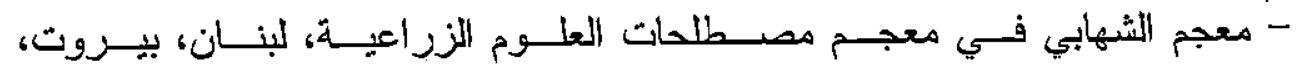
. $97 \mathrm{VA}$ مبكوليد محمود الجادر:

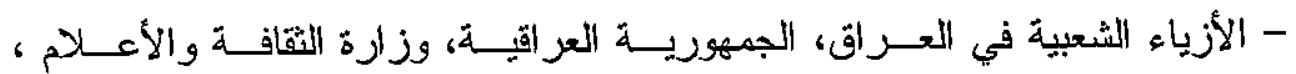

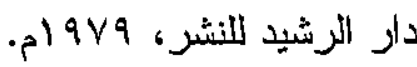
דr-و اضخح الصمد:

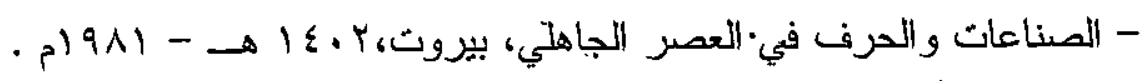

